\title{
Assessing the Endocrine Disrupting Effects of Chemicals on Invertebrates in the European Union
}

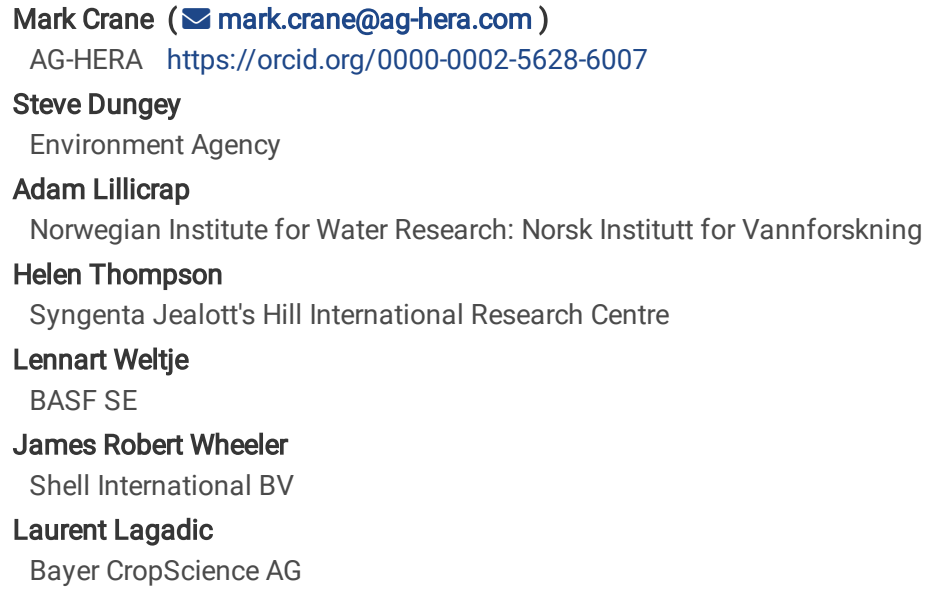




\section{Abstract}

Evidence from both laboratory and field studies has shown that currently used synthetic and naturally occurring chemical substances may potentially disrupt invertebrate endocrine systems, although the extent of this in field populations remains unclear. Translating concerns about potential endocrine disrupting chemicals (EDCs) into practical and effective regulatory action is currently hampered by the breadth of invertebrate endocrinology when compared to the better understood vertebrate systems, a lack of fundamental knowledge about the endocrinology of many invertebrate groups, and the resulting uncertainty when making regulatory decisions. This paper i) outlines the breadth of invertebrate endocrine pathways for which European Union regulation of potential EDCs may be relevant, ii) reviews the extent to which current knowledge meets regulatory requirements for invertebrates, including an assessment of the suitability of current invertebrate test guidelines for detecting endocrine modes of action; and iii) proposes a roadmap towards the regulation of potential EDCs with greater confidence, based on the Adverse Outcome Pathway (AOP) concept and a focus on identifying Molecular Initiating Events (MIEs) within AOPs. We propose that the most important research need is compilation of a comprehensive list of endocrine-related MIEs across invertebrate taxa via use of high throughput 'omics in combination with bioinformatics reverse engineered analyses. Although tractable, such an approach would require significant resource investment for development and implementation.

\section{Introduction}

Approximately $95 \%$ of all known animals are invertebrates (Ford and LeBlanc 2020), with an estimated 6.77 million invertebrate species worldwide (Chapman 2009) covering around 30 different phyla and spanning an enormous morphological and physiological range from sponges through to more complex arthropods (insects, crustaceans), molluscs, and tunicates (deFur 2004). In 2011, the International Union for the Conservation of Nature concluded that in Europe almost half of freshwater mollusc species and one-fifth of selected terrestrial mollusc species were threatened with extinction; $9 \%$ of European butterflies were threatened, with a further $10 \%$ considered near threatened; $11 \%$ of assessed saproxylic beetles were threatened, with a further $13 \%$ considered near threatened; and $15 \%$ of the 137 assessed (sub)species of European dragonflies were threatened, of which $2 \%$ were critically endangered, $4 \%$ endangered, and $9 \%$ vulnerable, with a further $11 \%$ considered near threatened (EC 2012). Some of the major threats to invertebrate biodiversity include habitat fragmentation, intense agricultural practices, and climate change (Collen et al. 2012).

Invertebrates use a variety of hormones for regulation of growth, development, reproduction, metabolism, and other physiological processes (deFur et al. 1999, Weltje and Schulte-OehImann 2007). The insect endocrine system is the specific target of a class of chemicals used for pest control, the insect growth regulators (IGRs), which are utilised in veterinary medicine, public health, and agriculture (Tralochand and Dhadialla 2012, Jindra 2021). IGR insecticides based on juvenile hormone receptor agonists have the potential to affect a wide range of insect taxa (Jindra and Bittova 2020). However, for other IGRs (e.g. ecdysteroid receptor agonists) selectivity towards specific insect orders, such as Lepidoptera and Coleoptera, has been identified (Smagghe 2008, Billas et al. 2009). Evidence from both laboratory and field studies has shown that certain other synthetic and naturally occurring chemical substances may also disrupt invertebrate endocrine systems. The iconic example of this is gastropod mollusc exposure to tributyltin (TBT) leading to imposex and large-scale population declines in the marine environment (Langston 2020). However, even in this well-known case the precise mechanism of action of TBT in gastropods has not been fully determined, the regulatory implication of which is reviewed in Lagadic et al. (2017). The effects of TBT on other invertebrate phyla, at concentrations lower than those causing imposex in gastropods, is also poorly understood and may have been overlooked. There is also other, less conclusive, evidence of endocrine disrupting (ED) effects associated with either measured or assumed exposure to other substances in field populations of invertebrates (Ford and LeBlanc 2020, Matthiessen et al. 2018), and laboratory studies have shown that invertebrate endocrine receptors may be affected by chemical exposure in a variety of different ways (Cuvillier-Hot and Lenoir 2020). As many invertebrate populations are in decline (Hallman et al. 2017, Hayhow et al. 2019), concerns about the possible contribution of endocrine-disrupting chemicals (EDCs) to this decline are justified, although the current extent of the problem remains unclear (Godfray et al. 2019).

Translating reasonable concerns about potential EDCs into practical and effective regulatory action is hampered by several obstacles when considering invertebrates. The first of these is the breadth of invertebrate endocrinology compared to the better understood vertebrate systems. Invertebrate hormones include steroids, proteins, terpenoides, and amides (deFur 2004). There are also some, such as ecdysteroids and juvenile hormones, that do not occur in vertebrates (LaFont 2000). A second obstacle is the lack of fundamental knowledge about the endocrinology of many invertebrate groups (Ford and LeBlanc 2020).

The identification of a chemical as an endocrine disruptor relies upon the demonstration that an adverse effect in an intact organism is the consequence of an endocrine mode of action (WHO-IPCS 2002, EC 2018a), so the paucity of mechanistic data available on invertebrate endocrine pathways is a real hurdle to the use of these organisms in regulatory assessment of environmental EDs.

A coherent conceptual framework for addressing these obstacles does not currently exist, most likely because the focus of regulatory science to date has been on vertebrates, so existing regulations on EDCs may not currently be directly applicable to invertebrates. To start to understand and address these scientific and regulatory gaps and challenges, the European Centre for Ecotoxicology and Toxicology of Chemicals (ECETOC) convened a group of experts to:

1. Outline the breadth of invertebrate endocrine pathways for which regulation of potential EDCs may be relevant, with a focus on the European Union (EU) regulatory context;

2. Review the extent to which current knowledge meets regulatory requirements for invertebrates, including an assessment of the suitability of Organisation for Economic Cooperation and Development (OECD) invertebrate test guidelines for detecting endocrine modes of action; and

3. Propose a pathway for regulation of potential EDCs in invertebrates with greater confidence, based on the Adverse Outcome Pathway (AOP) concept and a focus on identifying Molecular Initiating Events (MIEs) within AOPs. 


\section{Invertebrate Endocrine Pathways}

Invertebrate endocrine pathways are diverse and best understood for some arthropod groups (insects, crustaceans), and molluscs.

Three major classes of hormones are known in insects (Soin and Smagghe 2007):

- Peptide hormones, which are mainly produced in the central nervous system and midgut epithelium. For example, prothoracicotropic hormone which stimulates the prothoracic gland to produce ecdysone and adipokinetic hormone.

- Ecdysteroids, which are associated with moulting and metamorphosis and produced by the prothoracic gland in immature insects (usually as ecdysone, although some larval Lepidoptera secrete 3-dehydroecdysone, which is enzymatically converted to ecdysone in the haemolymph). Ecdysone, a prohormone, is then converted to the active hormone 20-hydroxyecdysone by a cytochrome P450 enzyme. In contrast, makisterone is the main ecdysteroid in the Hymenoptera (e.g. honeybees) and the Heteroptera (true bugs).

- Juvenile hormones modulate ecdysteroid action and are sesquiterpenes produced by the corpora allata. Juvenile Hormone III is the most common, although several different forms are known.

Three major classes of hormones are also known in crustaceans. Crustaceans and insects are closely related and belong to the same Clade (Pancrustacea), so some crustacean hormones are similar to those found in insects (Leblanc 2007, Knigge et al. 2021, Kusk and Wollenberger 2007):

- Peptide hormones, including:

- Crustacean hyperglycaemic hormones ( $\mathrm{CHHs}$ ), which are produced in the malacostracon $\mathrm{X}$ organ and stored and released from the sinus gland, both located in the eye stalk. Some $\mathrm{CHHs}$ regulate carbohydrate metabolism, while others regulate ecdysteroid synthesis, the secretion of methyl farnesoate, and gonadal maturation.

- Androgenic gland hormone, found so far in male isopod gamete ducts and are responsible for male sexual differentiation. Insulin-like androgen gland hormone and Crustacean Female Sex Hormone are also found in decapods (Toyota et al. 2021).

- Red pigment concentrating hormone and pigment dispersing hormone, which regulate colour change.

- Ecdysteroids, predominantly 20-hydroxyecdysone (as in insects).

- Methyl farnesoate, a terpenoid found in decapods, cirripedes, and anostracans, which has similar regulatory functions to insect Juvenile Hormone III, of which it is an unepoxidated form.

The major classes of hormones in molluscs are less well studied than those in insects and crustaceans, but the role of several neuropeptide hormones has been clearly demonstrated, particularly in the sea slug Aplysia and the pulmonate snail Lymnaea (Matthiessen 2008). Lagadic et al. (2007) summarised information on 11 different neuropeptides in Lymnaea, which regulate a wide range of behavioural, physiological, developmental, growth, and reproductive functions. Thyroid hormone receptors (THR), which are homologues to vertebrate THRs, have been identified in several molluscs (Huang et al. 2015, Wang et al. 2019), but the role of thyroid hormones, although identified, is still unclear in molluscs (Lustrino et al. 2017).

Hormones reportedly found in other invertebrate phyla (Dumollard et al. 2017, Oetken et al. 2004, Salzet 2001, Sugni et al. 2007, Takahashi 2020, Tarrant 2007) include:

- Cnidaria

- Neuropeptides: glycine-leucine tryptophan amides, involved in metamorphosis.

- Thyroids: thyroxine, involved in strobilation.

- Nematoda

- Ecdysteroids: reported but with a questionable functional role.

- Terpenoids: juvenile hormone-like hormones involved in growth.

- Neuropeptides: FMRFamide (function unknown).

- Annelida

- Ecdysteroids: ecdysone (function unknown).

- (Anti)diuretic neuropeptides: e.g. FMRFamide involved in neuromodulation.

- Echinodermata

- Steroids: progesterone, testosterone, 17-beta-estradiol, and estrone, involved in vitellogenesis, oogenesis, spermatogenesis, and spawning.

- Neuropeptides: gonad-stimulating substance involved in spawning; and maturation-promoting factor, involved in fertilization.

- Tunicata

- Steroids: testosterone and 17-beta-estradiol, involved in oogenesis, spermatogenesis, and spawning.

- Neuropeptides: gonadotropin releasing hormone analogue, involved in gonad development.

- Thyroids: thyroxine, probably involved in the tanning process during tunic formation.

The terminology used to name the hormones found in invertebrates has been constructed from the vertebrate hormonal system, but this does not necessarily imply that the molecular structures and physiological roles are the same in invertebrates (e.g. see Scott 2012, 2013). Therefore, the use of "steroid-like" or 
"thyroid-like" to designate invertebrate hormones which appear to be homologous to vertebrate hormones is usually preferable.

This brief summary illustrates the enormous breadth and diversity of invertebrate endocrine systems that might potentially be susceptible to an EDC, which is in sharp contrast to the current regulatory landscape that focuses on only four endocrine axes (Estrogen, Androgen, Thyroid, and Steroidogenesis; EATS) for vertebrates.

\section{EU Regulatory Framework for Assessing Endocrine Disruption in Wildlife}

In this section we describe the EU regulatory context for classification of a substance as an EDC in wildlife (both vertebrate and invertebrate) and the OECD testing framework which underpins the EU regulations.

Current EU policy on potential EDCs is summarised in EC (2018a), which states that:

- There is broad consensus on the WHO-IPCS (2002) definition of an EDC as "an exogenous substance or mixture that alters function(s) of the endocrine system and consequently causes adverse health effects in an intact organism, or its progeny, or (sub)populations". In this definition the term "(sub)population" is of relevance to humans, and for non-target organisms the term "population" is used synonymously in ECHA/EFSA (2018; see also Crane et al. 2019a).

- Test guidelines for non-vertebrates still require development or validation (with specific needs identified in EC 2018b).

- When scientific evaluation of potential EDCs comes to uncertain conclusions the Commission will be guided by the precautionary principle (EC 2000).

- Specific provisions on how to address endocrine disruption are included in regulations for plant protection products, biocides, chemicals in general, medical devices and water. In the case of plant protection products and biocides the Commission has established criteria for identifying EDCs and will develop a "horizontal approach" based on these criteria across all EU legislation. More recently the Commission is working towards including identification of EDCs within the Classification and Labelling Regulation that would apply to substances across several regulations.

Criteria for identifying EDCs in plant protection products and biocides therefore appear as a key component in both current and future EU regulatory frameworks. These criteria for wildlife (a term that includes invertebrates and vertebrates) are (EC 2018c):

1. The substance shows an adverse effect in non-target organisms, which is a change in the morphology, physiology, growth, development, reproduction or life span of an organism, system or (sub)population that results in an impairment of functional capacity, an impairment of the capacity to compensate for additional stress, or an increase in susceptibility to other influences (WHO-IPCS 2009);

2. The substance has an endocrine mode of action, i.e., it alters the function(s) of the endocrine system; and

3. The adverse effect is a consequence of the endocrine mode of action.

EC (2018c) further states that identification of a substance as an EDC must be based on:

1. All available relevant scientific data (in vivo, in vitro, and in silico) generated from internationally agreed study protocols or collected via a systematic review;

2. An assessment of the available relevant scientific data, based on a weight of evidence approach that considers:

a. Both positive and negative results, discriminating between taxonomic groups, where relevant;

b. The relevance of the study design for the assessment of the adverse effects plus its relevance at the (sub)population level and for assessment of an endocrine mode of action;

c. The adverse effects on reproduction, growth/development, and other relevant adverse effects which are likely to impact on (sub)populations;

d. Adequate, reliable, and representative field or monitoring data and results from population models, where available;

e. The quality and consistency of the data, considering the pattern and coherence of the results within and between studies of a similar design and across different taxonomic groups; and

$\mathrm{f}$. The concept of the limit dose and international guidelines on maximum recommended doses and for assessing confounding effects of excessive toxicity.

3. Using a weight of evidence approach, the link between any adverse effect(s) and an endocrine mode of action is established based on the current understanding of biological plausibility; and

4. Adverse effects that are non-specific secondary consequences of other toxic effects are not used to identify a substance as an EDC.

These criteria, mandated by the European Commission, do not consider environmental exposure concentrations or potency, so are hazard-based (with limited options for derogation such as negligible exposure and essential use) and not risk-based. The treatment of endocrine disruption is therefore similar to the treatment of Category $1 \mathrm{~A}$ or $1 \mathrm{~B}$ hazardous properties to humans, such as carcinogenicity, mutagenicity, and reprotoxicity. However, this is a problematic approach for substances such as IGRs because the Plant Protection Regulation EC 1107/2009 (incorporating EU 283/2013, EU 284/2014) specifically identifies the need for risk assessment of pesticides relative to defined population level protection goals. EC 1107/2009 also highlights that data generation should be designed appropriately to address the mode of action of IGRs in aquatic and terrestrial non-target arthropods (e.g. development and emergence of Chironomus larvae and honeybee broods). This means there is a disconnect in addressing both EC 1107/2009 and EC (2018c), because compliance with both regulatory demands requires an IGR pesticide risk assessment of non-target arthropod population-level protection goals for a chemical designed to target the endocrine system of the pest insect, whilst also confirming that there is no hazard to non-target insect species. The effect of this is highlighted by the EFSA conclusion for pyriproxyfen, a juvenile hormone analogue (EFSA 2019). With respect to EC (2018c) the conclusion states that "no data and methods are

Page $4 / 28$ 
available to further elucidate the specificity of the mode of action (MoA) for the target species and consequently possible endocrine mediated effects on nontarget invertebrates. According to point 3.8.2 of Annex II to Regulation (EC) No 1107/2009, as amended by Commission Regulation (EU) 2018/605, it can be concluded that pyriproxyfen is not an endocrine disruptor for non-target arthropods." However, it is unlikely that an IGR with an endocrine-directed mode of action would have effects limited only to the target pest species, even if it was designed to target a specific insect order. Thus, for these IGRs, even if the risk is identified as acceptable to non-target arthropods under EC 1107/2009, (e.g. due to low exposure), EC (2018c) considers that, as an EDC, the mode of action should be regarded as a hazard cut-off criterion, and even taxonomic order-specific insecticides should not be approved, with only limited options for derogation (negligible exposure and essential use).

Although, as shown above, hazard-based regulatory criteria can be contentious (Autrup et al. 2015, Bergman et al. 2013a, Crane et al. 2019 a\&b, Dietrich et al. 2013, Matthiessen et al. 2017, Solecki et al. 2017, Zoeller et al. 2014), it is still possible to develop an operational, hazard-based regulatory framework for potential environmental EDCs (e.g. Crane 2019a) which might be applied to invertebrates. This might be based on an expansion of the tools available within the OECD's Conceptual Framework (CF) for the Testing and Assessment of Endocrine Disruptors.

The OECD CF was adopted in 2002 and subsequently updated in 2012, forming the technical foundation of Guidance Document 150 (OECD $2018 \mathrm{a}$ ) and the EU's approach to ED identification. The OECD CF classifies environmental toxicity test information at five different levels from in silico through in vitro to in vivo:

- Level 1. Existing data and non-testing information (including in silico information);

- Level 2. In vitro assays which provide data about selected endocrine mechanism(s) and pathway(s);

- Level 3. In vivo assays which provide data about selected endocrine mechanism(s) and pathway(s);

- Level 4. In vivo assays which provide data about adverse effects on endocrine-relevant endpoints; and

- Level 5. In vivo assays which provide more comprehensive data about adverse effects on endocrine relevant endpoints over extensive parts of the life cycle of an organism.

Coady et al. (2017) reviewed available invertebrate test guidelines (as compiled in OECD 2018a) and concluded that there were none specifically designed for characterising endocrine activity (i.e. none that can identify mechanisms). However, they identified several apical endpoints in level 4 and 5 tests that may indicate adverse effects potentially related to endocrine dysfunction (Table 1). Therefore, there are no internationally validated invertebrate toxicity test protocols providing mechanistic information on the mode of action of test substances, so they are unable on their own to fulfil EC (2018c) criteria for identifying a substance as an EDC. ECETOC (2016) also noted that for invertebrates there are few mechanistic in silico, in vitro, and in vivo assays because invertebrate testing has focussed on capturing apical endpoints. This means that adverse outcomes in arthropods are well described, but the underlying mechanisms are often poorly understood. In relation to juvenile hormone and ecdysone modulation in chironomid, daphnid, and copepod tests, OECD (2018a) notes that there are no standardised in vitro screens for juvenile hormone or ecdysone (ant)agonists, although they cite relevant mechanistic assays reported by Cherbas et al. (1989), Dinan et al. (2001), Miyakawa and Iguchi (2017), Smagghe et al. (2003), and Swevers et al. (2003). Hartung et al. (2019) and OECD (2018c) provide detailed guidance on good in vitro reporting standards which could be applied to these assays to ensure they are fit for purpose.

In conclusion, there are no validated tools to determine any invertebrate endocrine mode of action in vitro or in vivo. However, there are commonly used invertebrate toxicity tests that might capture adverse effects that could potentially result from an endocrine mode of action but would not identify the causal mechanisms. Therefore, the EU regulatory requirements for the identification of EDCs cannot currently be satisfied for invertebrates, either for invertebrates in general or for the specific invertebrates used in standard ecotoxicological studies.

\section{Evidence for Invertebrate Endocrine Disruption in the Laboratory and Field}

In this section we examine available in vivo laboratory and field evidence for endocrine disruption in invertebrates at OECD CF Levels 3 to 5 . Later in this paper we discuss further development of in silico and in vitro approaches at CF Levels 1 and 2 which would complement and help prioritise these in vivo tests, so that they focus on the invertebrate endocrine pathways of greatest regulatory concern.

\section{Research trends}

Ford and LeBlanc (2020) reviewed research progress on endocrine disruption in invertebrates and found that there were fewer research citations for invertebrate EDCs when compared with fish EDCs in every time period they examined. They concluded from a survey of 46 experts in the field of endocrine disruption that there had been only limited advances over the previous two decades because of misconceptions about the relevance of vertebrate hormones to invertebrate endocrine pathways, with a focus on EATS modalities (Browne et al. 2020); lower public and regulatory interest in invertebrates when compared with vertebrates; lower funding for invertebrate endocrinology research; and a general lack of knowledge about invertebrate endocrinology which has hampered scientific understanding. In particular, several scientists who responded to the survey suggested a need for basic mechanistic endocrinology to allow full understanding of endocrine disruption and related population-level impacts in invertebrates.

We performed a further bibliographic assessment to assess whether there were any trends in invertebrate endocrine disruption research over the past decade. Derwent Innovation (2021) was searched for published articles from 2010 to 2020 which included the terms INVERT* and ENDOCRIN*. This provided a snapshot of relative research interest in different invertebrate taxa in relation to endocrinology. There were 1003 hits and these were reviewed manually to identify only primary research on potential invertebrate EDCs in either the laboratory or the field. One hundred and eighty-one published laboratory and field studies were identified in which invertebrates were either exposed in the laboratory or surveyed in the field, in studies with the explicitly stated purpose of detecting ED effects in invertebrates. In our analysis, mechanistic in vivo studies were defined as those at OECD CF Level 3, with apical studies defined as those at levels 4 and 5. 
Almost $60 \%$ of the reported studies were in freshwater species, with $28 \%$ in saltwater species and $12 \%$ in terrestrial species. Tables 2 to 4 summarise the invertebrate groups studied. This shows that although a wide range of invertebrates were used to assess potential endocrine disrupting effects, only the freshwater species Daphnia magna (Crustacea), Chironomus riparius (Insecta) and Potamopyrgus antipodarum (Mollusca), plus the saltwater species Mytilus galloprovincialis (Mollusca), were used extensively, with most other species studied only once or twice. Fourteen percent of freshwater studies were field- or semi-field (e.g. mesocosm) based, with the remainder being laboratory investigations, with mechanistic, apical, and mechanistic/apical studies split $45 \%, 22 \%$, and $27 \%$, respectively. Five percent of saltwater studies were field-based, with mechanistic, apical, and mechanistic/apical studies split $31 \%, 41 \%$, and $29 \%$, respectively. All terrestrial studies were laboratory-based, with mechanistic, apical, and mechanistic/apical studies split $13 \%, 61 \%$, and $26 \%$, respectively.

There was a similar spread in the 126 separate substances examined for ED properties in invertebrates in papers published between 2010 and 2020 . Most of these were industrial chemicals; pharmaceuticals; or agricultural/veterinary insecticides, herbicides, or fungicides. However, only 14 substances were tested in more than 5 studies (Table 5), most of which are known vertebrate EATS modulators and are likely to have been selected for this reason.

This bibliographic analysis suggests that most research interest in invertebrate endocrine disruption has been focused on standard laboratory-based freshwater model species, especially $D$. magna and $C$. riparius, although a wide range of freshwater and, to a lesser extent, saltwater species have also been studied. Endocrine disruption in terrestrial invertebrates remains relatively understudied, although IGRs have received considerable attention (Pener and Dhadialla 2012). Similarly, a wide range of potential EDCs (with a focus on vertebrate EATS modulators) have been tested across a wide range of different invertebrate species, although this makes it difficult to draw any conclusions about the utility of invertebrate models other than $D$. magna and $C$. riparius and, possibly, P. antipodarum, L. stagnalis and M. galloprovincialis.

\section{Laboratory-based effects of EDCs on invertebrates}

Reviews of laboratory evidence for invertebrate endocrine disruption are available for insects (Soin and Smagghe 2007, Weltje 2013), crustaceans (Breitholtz 2013, LeBlanc 2007, Tatarazako and Oda 2007, Verslycke et al. 2007), molluscs (Duft et al. 2007, Janer and Porte 2007, Lagadic et al. 2007, McClellan-Green 2013, Oehlmann et al. 2007, Scott 2012 \& 2013), echinoderms (Sugni et al. 2007), cnidarians (Tarrant 2007), and nematodes (Höss and Weltje 2007). However, beyond effects of IGRs on insects and TBT on molluscs, very few studies have unambiguously identified endocrine disruption as the cause of adverse effects on invertebrate development, growth, or reproduction (Hutchinson 2007). This is largely because of a lack of current methods to identify endocrine activity unambiguously in mechanistic tests with invertebrates.

EFSA SC (2013) and Munn and Goumenou (2013) point out that although insect or crustacean reproduction lifecycle assays may show "downstream" (i.e. apical) effects, no "upstream" standardised mechanistic assays for invertebrate EDCs are currently available and that these apical tests on growth, development, and reproduction cannot provide a firm diagnosis of a specific endocrine activity linked to a given adverse effect. Limited understanding of invertebrate endocrinology means that read-across to untested groups from tests with other vertebrate or invertebrate taxa is uncertain, and the current focus on EATS modalities ignores important invertebrate endocrine modalities such as peptide hormone pathways.

Coady et al. (2017) identify a significant data gap in understanding EDC hazards due to the lack of fundamental knowledge about endocrine pathways for many invertebrate species. They attribute at least some of the difficulty in addressing this to the large number of invertebrate species that exist, combined with the great diversity this group displays in the endocrine control of growth, development, and reproduction. They also identify this lack of understanding as leading to an unfortunate trend in the field, which is the assumption that indicators of endocrine activity in vertebrates (e.g. vitellogenin (VTG) induction by estrogens in (male) fish) equally applies to invertebrates, when this is often not the case. For example, the transcriptomic response of the Vtg2 gene in Daphnia magna is not elevated in response to chemicals with known estrogenic modes of action in vertebrates (Hannas et al. 2011), and there is no valid evidence that vertebrate sex steroids have endocrine or reproductive roles in either molluscs (Scott 2013, Morthorst et al. 2014) or crustaceans (Knigge et al. 2021, Short et al. 2014). Other authors have also argued that measurement of VTG in invertebrates is inappropriate for several reasons, including evidence that vertebrate steroids can be absorbed from the environment and retained for very long periods, and key enzymes required for the biosynthesis of vertebrate steroids (e.g. aromatase) do not appear to be present in invertebrates (e.g. Fernández-González et al. 2020, Fodor et al. 2020, Scott 2018). However, some researchers suggest that the presence of vertebrate steroids in invertebrates cannot be ignored because they can interact with multiple signalling components, leading to modulation of different physiological functions (e.g. Balbi et al. 2019, Fernandes et al. 2011, Janer and Porte 2007, Köhler et al. 2007, Tran et al. 2019). Measurement of VTG-like yolk proteins in invertebrates could potentially be relevant for ED identification in invertebrates when the endocrine control of reproduction has been elucidated. The problem with some previously reported analyses is that inappropriate methods have been used (e.g. use of alkali-labile phosphate as a surrogate for VTG-like proteins) as outlined by Morthorst et al. (2014). In addition, VTG-like protein changes have been linked to estrogenic effects in mollusc species when the estrogen receptor is inactive and does not bind estrogens. In contrast to this controversy over invertebrate steroidal hormone signalling, there is considerable evidence for thyroid-like hormone signalling in several invertebrate phyla (Taylor and Heyland 2017, Sainath et al. 2019).

In summary, the current lack of mechanistic laboratory methods to identify endocrine activity unambiguously in invertebrates hinders the application of the WHO-IPCS definition and established EU regulatory criteria for confirming a substance as an EDC.

\section{Field effects of EDCs on invertebrates}

Our bibliographic assessment suggests that recent field studies of potential invertebrate endocrine disruption are rare when compared to laboratory studies. Matthiessen et al. (2018) also concluded that there was very little evidence that occurrence of invertebrate endocrine disruption from exposure to current-use chemicals is widespread in the field, with the evidence "essentially non-existent" for crustaceans and the causal evidence for molluscs "rather weak". This was for various reasons, including an overall lack of studies and a lack of exposure measurement in some studies that have been reported, potential confounding effects from other substances or stressors (e.g. parasites), and the assumption that invertebrate hormone systems are similar to those of vertebrates. They 
identified some limited evidence to suggest that bivalve molluscs may be feminised after exposure to presumably oestrogenic sewage effluent or other sources. However, they concluded that, with the exception of organotins and molluscs, no studies have shown population-level impacts on invertebrates in the field.

In contrast, Cuvillier-Hot and Lenoir (2020) suggest that there is evidence of field ED effects in invertebrates, citing studies by Amiard and Amiard-Triquet (2015) and Jin et al. (2012). However, the latter study only investigated effects in fish and Amiard and Amiard-Triquet (2015) draw extensively on Bergman et al. (2013b) in their review of invertebrate field effects, so theirs is not a primary source. In fact Bergman et al. (2013b) concluded that little is known about the manifestation of endocrine effects on the reproductive system of either male or female invertebrates; field-based evidence of endocrine-mediated reproductive disorders in invertebrate males is scarce and solely concerns aquatic crustaceans and molluscs; chemical-related sex ratio imbalances associated with TBT, DDT, and municipal effluent exposure have been reported for wild molluscs; and little information is available on endocrine neoplasias in invertebrate species, with even less information linking any incidence of invertebrate neoplasia with contaminant exposure. Organotin effects on molluscs therefore remains the single conclusive example of ED effects on aquatic invertebrate populations in the field, with both mechanistic and apical supporting studies from the laboratory, although the precise mechanism of this EDC still remains unclear (Katsiadaki 2019, Lagadic et al. 2017, Matthiessen et al. 2018).

In terrestrial systems, Cuvillier-Hot and Lenoir (2020) implicate substances such as IGRs in potential adverse endocrine effects on terrestrial invertebrates such as honeybees, wild bees, moths, parasitic wasps, and beetles. However, as with aquatic invertebrates, the evidence is weak that such effects occur in natural field populations of non-target arthropods (Fourrier et al. 2015). The lack of evidence for any widespread ED effects on invertebrate wildlife populations might suggest that the hazards are negligible, although it is unclear whether this is a case of "absence of evidence" or "evidence of absence" (Matthiessen et al. 2018). It is therefore appropriate to ask a question posed more widely by Bergkamp (2016): are we searching for "phantom risks" or is there plausible field evidence for endocrine-mediated effects on invertebrates from exposure to current-use chemicals?

In their survey of experts, Ford and LeBlanc (2020) identified field investigations to answer this question as the first of four research needs relevant to invertebrate endocrine disruption assessment:

- Field investigations: the evaluation of invertebrate field populations with sensitivity to adverse demographic effects;

- Biological target discovery: evolutionary studies to identify common potential invertebrate EDC targets and any unique targets for particular phyla, and the development of biomarkers for specific interactions between EDCs and invertebrate molecular targets;

- AOP construction for plausible ED effects on invertebrate populations; and

- Laboratory corroboration of field observations to investigate adverse outcomes at environmentally relevant concentrations, although this is less relevant under a European hazard-based approach.

\section{Developing a framework for invertebrate EDC identification}

The preceding overview suggests that there are two main obstacles to developing a coherent and scientifically defensible framework for invertebrate EDC identification, comparable to the vertebrate OECD CF:

1. Limited scientific understanding of invertebrate endocrinology, especially for non-arthropods. This problem has been well known for at least two decades (deFur et al. 1999) and is unlikely to be resolved soon (Ford and LeBlanc 2020). Therefore, regulatory authorities can currently only make reliable decisions about EDCs based on vertebrate data.

2. A lack of mechanistic assays to identify endocrine modes of action in invertebrates (Breitholz 2013). This creates difficulties in attributing adverse effects on individuals or populations to a specific endocrine mode of action and therefore also makes it difficult to satisfy the WHO-IPCS definition of an EDC and to comply with EC (2018c) criteria for identifying EDCs.

Despite these obstacles, a defensible framework can be developed now and subsequently updated and improved as knowledge increases. This framework requires the following features:

1. Clear definition of invertebrate protection goals at the population level (which may differ between species in a similar way to protection goals for vertebrates);

2. Identification of assays which measure Molecular Initiating Events, Key Events, and Key Event Relationships along invertebrate-relevant AOPs (Ankley et al. 2010) and which are sufficient to link adverse outcomes plausibly to a substance with an invertebrate-relevant endocrine pathway; and

3. Identification of representative invertebrate model test species and assay measurement endpoints to support population protection goals for invertebraterelevant endocrine pathways.

\section{Invertebrate protection goals}

Both European regulation (EC 2018c) and public opinion (Crane et al. 2006) identify invertebrate populations as the focus of interest when developing regulatory protection goals for invertebrate wildlife. However, the enormous diversity of invertebrates when compared to vertebrates means that criteria must be agreed when selecting which species populations to prioritise for research into potential ED because it is not practically possible to test every invertebrate phylum. The ecosystem services approach is one framework that could be used to prioritise invertebrates of importance to humans (e.g. pollinators). Nontarget invertebrate wildlife populations provide a wide variety of ecosystem services including food (for consumption by humans and other wildlife), pollination, genetic resources (biodiversity), education and inspiration, aesthetic values, pest and disease regulation (e.g. spiders feeding on insect pests), seed and propagule dispersal, and recreation and ecotourism (e.g. butterfly-watching and shellfish collection) (EFSA 2010, Weltje 2013). The European Commission also identifies societal and ecosystem benefits as a key driver for research on potential EDCs (EC 2018b). The EFSA Scientific Committee (EFSA SC 2016) 
uses the concept of ecosystem services to derive specific protection goals (SPGs) for service-providing units (SPUs). An SPU can be any ecological entity that provides an ecosystem service (provisioning, regulating, cultural, or supporting services) to humans. EFSA SC (2016) states that the following need to be defined before setting an SPG: the ecological entity (e.g. individual, population, functional group, or ecosystem), the attribute of that entity (e.g. behaviour, growth, abundance, biomass, or ecosystem processes), the magnitude of effects (i.e. negligible, small, medium, or large), the temporal scale of effect for the attribute (e.g. duration and frequency), and the spatial scales (e.g. in-field and off-field patches of landscapes). If the ecological entity to protect is the population of a particular species, as stated in Regulation (EU) 2018/605 on EDCs (EC 2018a), then EFSA SC (2013, 2016) suggests that in most cases the attribute to be protected will be population dynamics (recruitment, size, and stability) in terms of abundance (e.g. numbers of individuals and their fitness) or biomass. For example, Table 6 shows definitions of SPGs for invertebrates potentially exposed to an insecticide (Hommen et al. 2015).

The proposed "horizontal approach" by the European Commission (EC 2018a) to identify EDCs that cause population-relevant effects might therefore involve the following if it is based, as stated, on the EU's current approach to plant protection products and biocides:

1. Identification of key invertebrate SPUs within an ecosystem services framework to ensure that all major groups are covered; and

2. Prevention of changes in the population abundance and biomass of these species which take them out of their range of natural variability.

Definition of invertebrate SPUs and SPGs can draw upon an expanding literature on the ecosystem services provided by both aquatic and terrestrial invertebrates, including insects (Noriega et al. 2018), terrestrial and freshwater invertebrates (Watt et al. 2011), marine and estuarine invertebrates (Somerfield 2011, Rife 2018), bivalve aquaculture (van der Schatte Olivier 2020), and non-cultured shellfish (Carss et al. 2020). In the absence of any additional ecological or toxicological information on the functional importance or vulnerability of particular invertebrate phyla, we propose that the selection of appropriate invertebrate SPUs may be based on relative species richness and phylogenetic relationships, as well as information on any unique invertebrate endocrine pathways. This would ensure that the most important invertebrate groups in relation to abundance and biomass are considered, phylogenetic similarities and dissimilarities between groups are taken into account, and toxicity testing is kept to a reasonable minimum.

We recognise that an ecosystem services approach is an explicitly anthropocentric and contested framework (Schröter 2014). However, the conceptual domain of invertebrate endocrine disruption must be bounded somehow, even if only imperfectly. This can then be subject to regular review and the boundaries can, if necessary, be redrawn in the light of new knowledge. If such boundaries are not set then regulatory authorities are faced with an apparently limitless and therefore impossible task: to protect an ill-defined set of "all invertebrates", including currently unknown or understudied species and endocrine pathways, against exposure to currently unknown EDCs.

\section{Adverse Outcome Pathways for invertebrate EDC identification}

There is a developing consensus in the (eco)toxicological and regulatory communities that different outputs from in silico predictions, in vitro and in vivo assays, and population modelling may usefully be considered within an AOP framework. The AOP concept is a robust way to organize information on potential EDCs and help support regulatory decision-making (Ankley et al. 2010, Kramer et al. 2011, Becker et al. 2015, Wheeler and Weltje 2015, Edwards et al. 2016, Hecker and LaLone 2019, Villeneuve et al. 2014a). The concept is chemically "agnostic" (i.e., not specific to an individual substance) and can be used to describe the actions of a group of chemicals (Perkins et al. 2019a\&b). It can therefore be used to reflect the definition of an EDC: requiring an endocrine mechanism (i.e. a molecular initiating event [MIE]), causally linked (via key events [KEs] and key event relationships [KERs]) to a population-relevant adverse outcome (AO), although the KER that links an individual outcome to a population-relevant AO is usually derived "by extension" (Ankley et al. 2010; see also Lagadic et al. 2020). An AOP may describe a sequence of KEs from MIE to AO either linearly or, in most cases and more realistically, through network effects if KEs are shared amongst AOPs (Knapen et al. 2018, Villeneuve et al. 2018).

A cascade of effects through an AOP from an MIE to an AO requires sufficient chemical potency and exposure for a KE to activate the next step in the chain (Lagadic et al. 2020). Consequently, an AO may not manifest if a non-responding KE interrupts the process. Criteria for determining the biological plausibility of an AOP, for both vertebrate and invertebrate endocrine disruption, must therefore include, as a minimum (Becker et al. 2015, OECD 2017):

1. Biological plausibility: Is there a mechanistic (i.e., structural or functional) relationship between upstream and downstream KEs which is consistent with established biological knowledge?

2. Essentiality: Are downstream KEs or the AO prevented if an upstream KE is blocked?

3. Empirical evidence:

a. Does the empirical evidence support the inference that a change in an upstream KE leads to an appropriate change in a downstream KE?

b. Does each upstream KE occur at lower doses and earlier time points than the associated downstream KE and is the incidence of the upstream KE greater than that for the downstream KE?

c. Are there inconsistencies in empirical support across taxa, species, and stressors that do not align with an expected pattern for the hypothesized AOP?

There is now considerable guidance on best practice for constructing AOPs and defining their constituent MIEs, KEs, KERs, and AOs (Villeneuve et al 2014a\&b, OECD 2017, OECD 2018a\&b). Development of fully quantitative AOPs (qAOPs) is the "holy grail" (Conolly et al. 2017, Perkins et al. 2019a\&b), but even a semiquantitative AOP is likely to be considerably useful for regulatory purposes (Perkins et al. 2019b). This is because quantitative, invertebrate-relevant, in vitro mechanistic assays can be anchored to one end of the pathway, and a quantitative invertebrate population-relevant $A O$ anchored to the other end, with intermediate KEs inferred. (Semi)quantification overcomes the criticism that qualitative AOPs do not demonstrate exceedance of a toxic threshold and therefore do not demonstrate the plausibility and essentiality of each KE (Wheeler and Weltje 2015). 
Hecker (2018) noted that only a limited number of "mature" AOPs are available, especially for microorganisms, invertebrates, and plants, because most work has focused on vertebrates (Browne et al. 2017). Currently (December 2021), there are three AOP Wiki descriptions of specific relevance to invertebrate endocrine disruption:

- An AOP for juvenile hormone receptor agonism leading to male offspring induction and associated population decline, with taxonomic applicability to $D$. magna and D. pulex (and potentially other crustaceans and insects) (https://aopwiki.org/aops/201).

- Ecdysone receptor (EcR) agonism leading to incomplete ecdysis-associated mortality, with taxonomic applicability to $D$. magna (and potentially other crustaceans and insects) (https://aopwiki.org/aops/4).

- 5-Hydroxytryptamine transporter (5-HTT) inhibition leading to population increase, with taxonomic application to molluscs (https://aopwiki.org/wiki/index.php/Aop:195).

Song et al. (2017) provide a detailed AOP for ecdysone receptor agonism leading to lethal moulting disruption in arthropods, which illustrates the utility of the approach (Table 7). This AOP should be applicable to both steroidal (e.g. ecdysone) and non-steroidal (e.g. tebufenozide) EcR agonists. The AOP includes empirical data from insects (Diptera, Lepidoptera, and Coleoptera) and crustaceans, although the authors note that crustacean-based evidence for certain elements of the pathway is sparse. However, they point out that both the EcR and the role of ecdysis triggering hormone (Eth), in stimulating muscle contraction behaviour required for ecdysis, are considered well conserved across arthropods. They therefore conclude that "based on evaluation of known sequence conservation and phylogenetic relationships, it is expected that this AOP may be applied broadly to most arthropods, although differences in the exact nature of quantitative relationships between some of the KEs may vary among taxa."

As Fay et al. (2017) point out in case studies for ecdysone receptor agonism and 5-HTT inhibition, these AOPs are based on substantial prior knowledge of invertebrate endocrinology and MIEs. This highlights the significant resource investment that would be required to implement such approaches even for a limited number of pathways and relevant surrogate species with "adequate" taxonomic coverage. However, the AOP framework also encompasses useful approaches for identifying previously unknown MIEs, as addressed below.

\section{Identification of Molecular Initiating Events at OECD CF Levels 1 and 2}

An MIE is the initial interaction between an exogenous molecule and a biomolecule or biosystem that can be causally linked to an outcome via a pathway (Allen et al. 2014). Identification of relevant MIEs is not just an important technical prerequisite when developing an AOP. In the case of invertebrate endocrine disruption, it is probably the key requirement when one considers the current lack of knowledge about invertebrate endocrinology and the lack of tools to assess chemical interactions with invertebrate endocrine activity.

MIEs possibly relevant for invertebrate endocrine disruption may be identified in four main ways:

1. Prior knowledge of invertebrate endocrine pathways. However, as we have seen, this knowledge is patchy, limited to a few taxa (e.g. honeybees, silk moths, shrimps, and mussels), and considers only a small number of pathways.

2. Regulatory authorities could request that additional studies might be performed if concerns about potential ED effects are triggered, either by findings in core guideline (toxicology and ecotoxicology) studies (e.g. at OECD CF Levels 3 , 4, or 5) or if there is a concern triggered by a substance's mode of action and its potential to cause an MIE (Day et al. 2018). However, in a hazard-based framework there is little point in performing an invertebrate test to determine whether a substance is an EDC if it has already been classified as such from vertebrate tests, and a means must also be found to confirm an endocrine mode of action if in vivo adverse effects are found in non-target invertebrates.

3. By using chemical structural alerts to prioritise substances with structures known to disrupt vertebrate pathways which appear to be conserved in invertebrates (Allen et al. 2018 \& 2020, Gunnarsson et al. 2008, Kostich and Lazorchak 2008, LaLone et al. 2014), or with structures known to disrupt only invertebrate pathways (e.g. Mellor et al. 2020). However, once again this approach would be redundant for hazard classification if a substance is already known to be a vertebrate EDC, and it does not solve the problem of potential effects on currently unknown invertebrate endocrine pathways.

4. By using high throughput "omics" datasets (e.g. transcriptomics, metabolomics, lipidomics, and proteomics (Brockmeier et al. 2017, Martyniuk and Simmons 2016, McBride 2018, Thomas et al. 2017, Van Aggelen et al. 2010)) to explore changes in genetic, metabolic, lipid, or protein structures after exposure to a chemical at any CF Level. Data from these assays can then be used in "reverse engineering", "right-to-left", or "top-down" AOP development to identify MIEs (Khammash 2018, Leonard et al. 2018, Perkins et al. 2011, Quercioli et al. 2018, Sewell et al. 2018, Villaverde and Banga 2014, Vinken 2019).

It is the last of these that holds the greatest promise for providing reassurance that potential EDCs, which specifically interact within non-target invertebrate endocrine pathways, will be identified.

There is a pressing need for research to support development of additional invertebrate-specific EDC screening tests and a first step is to characterise at the molecular and functional level the many nuclear receptors present in invertebrates (Coady et al. 2017). For example, Oliveira et al. (2016) list 36 nuclear receptor families and their physiological ligands which are known to occur in arthropods. These authors and others (e.g. Ankley et al. 2016, Piersma et al. 2018) recommend high throughput screening tools and other rapid and relatively inexpensive alternatives to in vivo vertebrate testing. Castro and Santos (2014) have also called for comprehensive analysis and functional characterisation of nuclear receptors across invertebrate lineages so that the extent of receptor conservation can be determined and relevant in vitro assays developed for cost-effective high throughput testing. Drug discovery already uses invertebrate models such as Caenorhabditis elegans and Drosophila melanogaster to identify bioactive compounds and to understand their mechanism of action (Giacomotto and Ségalat 2010). Kaur et al. (2021) provide a recent systematic review of computational techniques and tools for 'omics data analysis which identifies promising techniques that might be used to identify MIEs. 
A key requirement in developing AOPs is to build a community of biologists and modellers because both high throughput, mechanistic in vitro and in vivo assays, and predictive computational modelling are necessary to define MIEs and early KEs (Wittweher et al. 2017). For example, Hodges et al. (2018) discuss how the use of genome-wide RNA profiling and non-targeted metabolomics can be used to analyse networks of genes and metabolites showing reproducible correlations across multiple samples and test conditions. Machine learning techniques can relate the different 'omics data types in a way that is more powerful than reliance on shared sequence similarity to infer functional homology. In another example, Perkins et al. (2011) describe use of a network inference approach to pathway discovery.

LaLone et al. (2016) suggest that if the molecular target of a chemical is unknown then in vitro data (e.g. from USEPA ToxCast (Kavlock et al. 2012, Filer et al. 2014, Reif et al. 2010, Rotroff et al. 2013)) might be used to identify potential protein molecular targets, or it may be possible to assign tentative molecular targets based on information from structurally similar chemicals that have been tested. Hodges et al. (2018) note that while there is a wealth of results from receptor binding assays (e.g. from ToxCast), these have not yet been systematically reviewed to determine how many are relevant and valid for invertebrates. Madden et al. (2014) also note that in vitro tools complement in silico tools by verifying the domain of applicability of structural alerts identified in silico and corroborating proposed mechanisms, and Schroeder et al. (2016) show how they can be used to trace mixture toxicity pathways and effects within an AOP framework.

The number of screening tests required to cover each important invertebrate-specific endocrine pathway need not be large but, depending on the number of pathways required to be investigated, could multiply rapidly. However, Judson et al. (2017) demonstrated for vertebrates that adequate predictive power could be obtained from using a subset of only four out of 16 USEPA screening tests for estrogen agonism. A similar approach can be used to identify a minimum set of in vitro assays for reliable determination of juvenile hormone receptor agonism, ecdysone receptor agonism, 5-HTT inhibition, and any other identified invertebrate endocrine pathways of concern.

Mihaich et al. (2017) highlight the wide range of different species that need to be protected, which presents a challenge because the molecular targets and associated toxicity pathways for EDCs can differ among species. As a result, there has been a focus on developing computational approaches to compare target molecules of MIEs or KEs among taxonomic groups to enable initial predictions to be made about adverse outcomes. An example tool is the USEPA's Sequence Alignment to Predict Across Species Susceptibility (SeqAPASS) which aligns the sequence of the functional molecule representing an MIE, such as a receptor or enzyme which has been shown to trigger an adverse effect (Lalone et al. 2013a\&b, 2014, 2016, 2018). There is a strong correlation between SeqAPASS susceptibility predictions for vertebrate and invertebrate aquatic species and empirical toxicity data, so this and other molecular target sequence tools can identify taxa affected by common endocrine MIEs. LaLone et al. (2018) conclude that high throughput screening targets of regulatory relevance are likely to be broadly applicable across most vertebrate taxa and some targets may be applicable to certain invertebrates. Subsequent in vitro and in vivo studies can then provide further empirical evidence to determine whether a substance is an EDC. This creates positive feedback, particularly between in silico predictions and high throughput in vitro tests for these predictions. SeqAPASS uses the National Center for Biotechnology Information protein database, which includes protein sequences for thousands of vertebrates, invertebrates, plants, bacteria, and viruses. Houck et al. (2021) show the predictive potential of SeqAPASS across vertebrate taxa, and LaLone et al. (2018) show how SeqAPASS can be used to identify high throughput mammalian ToxCast screens for steroidogenic and thyroid targets that may also be relevant for invertebrate taxa. SeqAPASS analyses of enzymes involved in steroidogenesis suggest that results from the human cell-based High Throughput-H295R assay may be broadly extrapolated to other vertebrates, but not invertebrates. Level 1 and 2 evaluations of human THRa and THR $\beta$ and their respective ligand binding domains showed that these receptors are well conserved across vertebrates, with the exception of Ceratodontimorpha (lungfish). Conservation of THR $\beta$ but not THRa is also found for several invertebrate taxa, including Polychaeta (sandworms), Gastropoda, Lingulata (lampshells), Bivalvia, Enteropneusta (acorn worms), Asteroidea (starfish), Branchiostomidae (lancelet), and Ascidiacea (sea squirts, tunicates). Similarly, lodothyronine Deiodinase 1 (DIO1) and DIO3 are also found in invertebrate species, but DIO2 is not. Further work is required to understand the functional role of these proteins in invertebrates and to determine whether tools such as SeqAPASS are useful for non-vertebrates. If so, such tools could be augmented further by integrating information on chemical toxicodynamic and toxicokinetic properties so that species differences in absorption, distribution, metabolism, and excretion are also taken into account (Hecker 2018). This approach is not currently immediately applicable to invertebrates because the necessary in silico approaches and in vitro assays are still missing, and knowledge of chemical toxicodynamics and toxicokinetics in invertebrate taxa of interest for endocrine disruption assessment is very fragmented.

Coady et al. (2019) provide an example from vertebrate toxicology which shows how regulatory pressure can stimulate work on MIE identification and the development of appropriate high throughput assays. They describe how the USEPA identified 15 potential MIEs for thyroid-based AOPs, including those related to thyroid hormone synthesis, transport, nuclear receptor binding, and effects in peripheral tissues (USEPA 2017, Villeneuve et al. 2018). The USEPA then ranked these MIEs based on their relevance to the thyroid pathway, their toxicological potential, and the current status of high throughput bioassay development. Four MIEs from this thyroid AOP network (the sodium iodide symporter, thyroperoxidase, iodothyronine deiodinase, and hepatic nuclear receptors involved in thyroid metabolism) were ranked highest for bioassay development. Similar regulatory pressure to identify invertebrate-specific endocrine MIEs would most likely stimulate and accelerate similar research and development activity.

\section{Invertebrate model species at OECD CF Levels 3, 4, and 5}

Bioinformatic reverse engineering, from high throughput in vitro 'omics assays, is proposed above as the most efficient and effective way to determine MIEs with a potential ED mode of action. However, can we ever hope to provide a reasonably comprehensive framework that will identify EDCs across all invertebrate taxa without substantially expanding the range of invertebrate model species used in vivo?

Chapman (2009) reviewed the number of species in each invertebrate phylum and identified the 12 with the greatest estimated number of species, in order of richness, as Insecta, Arachnida, Nematoda, Mollusca, Crustacea, Myriapoda, Platyhelminthes, non-insect Hexapoda, Annelida, Porifera, Echinodermata, and Cnidaria. Integration of knowledge about the relative number of species within different invertebrate phyla, their conservation status, and their phylogenetic 
relationships (Budd and Mann 2020, Erwin et al. 2011, Erwin 2015) suggests that a reasonably comprehensive testing strategy for invertebrate EDCs could be based on representative models from the following phyla:

1. Arthropoda (Insecta, Arachnida, Crustacea, or Myriapoda);

2. Mollusca;

3. Annelida; and

4. Cnidaria

Of these four phyla, only Cnidaria are not currently included in international test guidelines for testing chemicals with invertebrates, although protocols for suitable test species are available (Howe et al. 2012, 2014, 2015). A case for testing based primarily on species richness and numerical dominance might also be made for inclusion in this list of Nematoda, with use of C. elegans as a representative model species (Höss and Weltje 2007) and for which an ISO test standard exists. However, there is no indication from either terrestrial or aquatic field studies that reliably suggests EDC-related population effects in any invertebrate phyla other than molluscs, although this may be due to a lack of relevant studies. The added value of annelid, cnidarian, and nematode models is therefore debatable.

There does not appear to be a compelling case to expand the battery of invertebrate in vivo tests for endocrine disruption unless further research reveals unique endocrine pathways sensitive to EDCs in invertebrates other than arthropods and molluscs.

Invertebrate population modelling

Adverse population effects are the AOs most commonly identified as a requirement by regulatory authorities in AOPs for non-endangered wildlife species (Kramer et al. 2011), although the regulatory approach for endangered vertebrate species often focuses more on the protection of individuals and a similar approach may also be relevant for endangered invertebrate species. Devillers and Devillers (2013) review models for projecting the population consequences of effects on juvenile hormone pathways in non-target species, including invertebrates. They describe simple equation-based models (e.g. Hill 1997) and slightly more complex matrix models (Kuhn et al. 2000, Raimondo and McKenney 2005, Tanaka 2003) that have been used to project the effects of methoprene exposure on aquatic crustacean populations. They also compare the utility of compartment models (Thompson et al. 2007) versus individualbased models (IBMs, sometimes known as agent-based models [ABMs], Devillers et al. 2014) for projecting the effects of insecticide exposure on honeybees. They conclude that IBMs provide more realistic and robust results than other methods because they account for the continuous development and interaction of individuals throughout their lifetimes and within their population in ways that can be related to environmental parameters.

In contrast to a species-specific model, a biological traits-based approach (Rico and van den Brink 2015, Rubach et al. 2011, van den Berg et al. 2019) could be used to develop a generic invertebrate model which includes realistic worst case sensitivity traits for adverse population effects. Invertebrate traits that have been considered include voltinism; asexual/sexual reproduction; maximum lifespan; lifecycle duration; lifecycles per year; maximum body size; feeding type and habit; oxygen source and respiration type; mobility; dispersal mechanisms; and current, salinity, temperature, and pH preferences (Rubach et al. 2010). For example, Rubach et al. (2010) found that self-fertility/asexuality versus sexual reproduction, plus temperature preference, were the traits most associated with sensitivity to organophosphate insecticides in aquatic macroinvertebrates. van den Berg et al. (2019) also found that in aquatic macroinvertebrates, carbamate toxicity was positively associated with $\mathrm{pH}$ preference and negatively associated with lifecycle duration and numbers of lifecycles per year. An analysis of invertebrate traits most associated with sensitivity to known EDCs would provide parameters for construction of population models either for focal species with these traits or for "generic" invertebrate species with biologically compatible sets of these traits. Model projections can then be used to assess whether any effects observed in endocrine disruption-relevant invertebrate toxicity tests will translate into population-level effects for the most demographically sensitive focal or generic species. ECETOC (2016) also supports a traits-based approach when extrapolating AOPs across species and argues that aspects other than taxonomic relatedness should be considered, such as reproductive strategies (e.g. uni- versus multivoltinism and r- versus $\mathrm{K}$ strategists), which can compensate for stress at the population level. There are multiple modelling and comparative studies showing that some traits that are sensitive to toxicants, such as reproduction in certain species, can have a very low impact on population growth (e.g. Forbes et al. 2010, Pfister 1998), although this will depend on the life history strategy of each species.

EFSA SC (2017) suggests that population models can be used for setting a critical effect level (i.e., a benchmark response). They envisage that models of focal species could be used to determine endpoints corresponding to cut-off values set by ecosystem service specific protection goals. These models can be used for calculating critical effect levels for certain types of effect. Forbes et al. (2017) also show how mechanistic dynamic energy budget models can be used to link organism-level responses measured in standard toxicity tests to protection goals relevant to ecosystem services. EFSA SC (2016) specifies that population resilience depends on the ecological context and is related to the degree to which induced fluctuations in the population density are buffered by density-dependent feedback mechanisms and competition with other species. For example, small effects on fecundity in density-regulated systems (e.g. a slightly reduced number of eggs for insects that produce many more eggs than develop into adults) will not translate adversely to the population level if egg quality remains unaffected. Although implicit in the use of organism-level toxicity data in effects assessments, it is invalid to assume that responses at the organism level are directly proportional to responses at the population level (Forbes et al. 2016). This is why qualitative population inferences, based only on individual organism effects observed in toxicity tests, should be quantitatively examined with population models, preferably also including interspecific interactions. If this is not performed then such qualitative inferences remain speculative and may lead to false conclusions.

\section{Knowledge gaps}

An expert group convened by the European Commission (EC 2018b) identified the following priority knowledge gaps in relation to invertebrate endocrine disruption assessment: 
- Invertebrate endocrinology/physiology (highest priority);

- Mechanistic understanding for invertebrates (particularly molluscs);

- Echinoderm developmental research; and

- Retinoic X Receptor (RXR) research in invertebrates, specifically molluscs, as an example of the most vulnerable species.

The group recommended that no further mollusc guideline development for endocrine disruption endpoints should take place until further research has adequately described mollusc physiology, endocrinology, and metabolic pathways. They also suggested that the six reporter assays for trans-activation of retinoic acid receptors in the ToxCast battery could be developed and validated for screening (US EPA 2017, Coady et al. 2017). This is because RXR and Retinoic Acid Receptors (RAR) are well conserved and would therefore be relevant across many different taxa potentially exposed to retinoids (Kubickova et al. 2021). Further suggestions were that the role of RXR in invertebrates should be investigated in molluscs (it can be cloned for several mollusc species (Vogeler et al. (2017)); and there should be development of in vitro receptor assays for juvenile hormone and ecdysteroids. This will link adverse outcomes to these pathways and provide additional mechanistic data to support endpoints for male production in the Daphnia reproduction test and in a short-term juvenile hormone activity screening assay currently under development (SJHASA - see Table 1). Invertebrate hormone analysis within existing apical invertebrate tests was also suggested as potentially useful (e.g. ecdysis triggering hormone levels or ecdysterone levels measured in arthropods).

Specific test development recommendations from this expert group were:

- Growth and development

- Validation by OECD of in vitro assays for RXR and RAR (OECD CF 2)

- Validation by OECD of in vitro Peroxisome Proliferator-Activated Receptor $(a, \beta / \delta, \gamma)$ transactivation assays (OECD CF 2$)$

- In vitro daphnid juvenile hormone and ecdysone agonist assay development (OECD CF 2)

- In vivo assay development for ecdysis triggering hormone levels (OECD CF 3)

- In vivo assay development for ecdysterone levels in arthropods (OECD CF 3)

- Reproduction

- In vivo spawning assay development in echinoderms (OECD CF 3)

Bopp et al. (2017) documented a survey of experts who also identified endocrine mechanistic screening tests for invertebrates as a priority research need.

Our assessment of the current state of knowledge largely supports these conclusions. However, our main initial focus would be on the development of 'omics data that can be reverse engineered through use of bioinformatics techniques to identify a comprehensive set of invertebrate-specific, endocrine-related MIEs, which represent the most important invertebrate taxonomic groups.

\section{Conclusions}

For more than twenty years, the knowledge gap in relation to invertebrate biodiversity and endocrinology has been a common theme in the scientific and technical literature. In this paper we have tried to focus more on what we do know and whether this knowledge is sufficient to construct a robust regulatory framework for identifying invertebrate EDCs.

Regulatory authorities agree on the WHO-IPCS (2002) definition of an endocrine disruptor, which forms the basis of current EU regulation (EC 2018a). The common protection goal for invertebrate wildlife is at the population level, which translates into no individual adverse effects that are relevant for population dynamics, abundance, or biomass. There is very limited evidence for endocrine-mediated effects of current use chemicals on non-target invertebrate populations in the field, with possible effects on arthropods or molluscs inferred in only a very small number of studies. However, the low number of relevant field studies means that it remains unclear whether this is evidence of absence or just an absence of evidence.

Arthropods and molluscs comprise almost $80 \%$ of the estimated total number of living invertebrate species and are also amongst the most important in providing ecosystem services, so it is a logical starting point to focus regulatory attention on these phyla. Several major invertebrate-relevant endocrine pathways are reasonably well understood, particularly for insects and crustaceans (and therefore probably for most arthropods) and also for molluscs. For insects these pathways involve peptide hormones, ecdysteroids, and juvenile hormones; for crustaceans these pathways also involve peptide hormones, ecdysteroids, and methyl farnesoate; and for molluscs these pathways are mainly based on peptide hormones. In silico and in vitro mechanistic assays are available or under development for some of these endocrine pathways, and high throughput 'omics approaches combined with bioinformatics could be used to reverse engineer AOPs to identify additional invertebrate ED MIEs for currently unknown pathways. Once endocrine MIEs are identified, in silico tools such as SeqAPASS are available to assess the likely susceptibility of different invertebrate taxa based on receptor homology. However, much of the information required to build reliable AOPs, which are meaningful for regulatory use, is still unavailable. There are some promising initiatives, but the scientific community remains far from being able to cover the diversity of signalling pathways within the major invertebrate taxa, not to mention those of lesser scientific interest.

Data on AOP KEs further downstream can be obtained from invertebrate tests performed according to internationally validated test guidelines available for insects, crustaceans, and molluscs with apical endpoints potentially relevant at the population level. Population models, including those based on sensitive invertebrate traits, can then be built to determine whether apical effects found in invertebrate tests are likely to cause adverse population level effects in a similar way to that recommended for non-target vertebrates by Crane et al. (2019b). An AOP for each known invertebrate endocrine pathway can therefore be anchored at both ends (mechanistic and population adverse outcome), although some intermediate KEs and KERs may at first be poorly understood. This approach is tractable but would require significant resource investment for development and implementation.

Page $12 / 28$ 


\section{Abbreviations}

5-HTT 5-Hydroxytryptamine Transporter

AO Adverse Outcome

AOP Adverse Outcome Pathway

CF Conceptual Framework

$\mathrm{CHH}$ Crustacean Hyperglycaemic Hormone

DIO lodothyronine deiodinase

EATS Estrogen, Androgen, Thyroid, and Steroidogenesis

EC European Commission

ECETOC European Centre for Ecotoxicology and Toxicology of Chemicals

ECHA European Chemicals Agency

EcR Ecdysone Receptor

ED Endocrine disruptor

EDC Endocrine Disrupting Chemical

EFSA European Food Safety Authority

Eth Ecdysis triggering hormone

EU European Union

IGR Insect Growth Regulator

IPCS International Programme on Chemical Safety

KE Key Event

KER Key Event Relationship

MIE Molecular Initiating Event

OECD Organisation for Economic Cooperation and Development

qAOP quantitative Adverse Outcome Pathway

RAR Retinoic Acid Receptor

RXR Retinoic X Receptor

SC Scientific Committee

SeqAPASS Sequence Alignment to Predict Across Species Susceptibility

SJHASA Short-term Juvenile Hormone Activity Screening Assay

SPG Specific Protection Goal

SPU Service-Providing Unit

TBT Tributyl tin

THR Thyroid Hormone Receptor

USEPA United States Environmental Protection Agency

VTG Vitellogenin

WHO World Health Organisation 


\section{Declarations}

Ethics approval and consent to participate (not applicable)

Consent for publication (not applicable)

Availability of data and material: The datasets used and/or analysed during the current study are available from the corresponding author on reasonable request.

Competing interests: HT, LW, JRW, and LL are employed by chemical manufacturing companies.

Funding: MC was funded by the European Centre for Ecotoxicology and Toxicology of Chemicals (ECETOC).

Authors' contributions: Each author made substantial contributions to the interpretation of data, drafting and revising the paper and approving the submitted version. Each author agrees both to be personally accountable for their own contributions and to ensure that questions related to the accuracy or integrity of any part of the work, even ones in which they was not personally involved, are appropriately investigated, resolved, and the resolution documented in the literature.

Acknowledgements: This paper benefited from review by and input from the ECETOC Scientific Committee. The authors also thank Henrik Holbech, University of Southern Denmark for critical reading and suggestions.

\section{References}

1. Allen TEH, Goodman JM, Gutsell S, Russell PJ (2014) Defining Molecular Initiating Events in the Adverse Outcome Pathway framework for risk assessment. Chem Res Toxicol 27:2100-2112.

2. Allen TEH, Goodman JM, Gutsell S, Russell PJ (2018) Using 2D structural alerts to define chemical categories for molecular initiating events. Toxicol Sci 165:213-223.

3. Allen TEH, Goodman JM, Gutsell S, Russell PJ (2020) Quantitative predictions for Molecular Initiating Events using three-dimensional Quantitative Structure-Activity Relationships. Chem Res Toxicol 33:324-332.

4. Amiard J-C, Amiard-Triquet C (2015) Ecotoxicological risk of endocrine disruptors. In: Amiard-Triquet C, Amiard JC, Mouneyrac C (eds) Aquatic Ecotoxicology. Elsevier, Amsterdam pp. 355-382.

5. Ankley GT, Bennett RS, Erickson RJ, Hoff DJ, Hornung MW, Johnson RD, Mount DR, Nichols JW, Russom CL, Schmieder PK, Serrrano JA, Tietge JE, Villeneuve DL (2010) Adverse outcome pathways: a conceptual framework to support ecotoxicology research and risk assessment. Environ Toxicol Chem 29:730-41.

6. Ankley G, LaLone C, Gray LE, Villeneuve D, Hornung M (2016) Evaluation of the scientific underpinnings for identifying estrogenic chemicals in nonmammalian taxa using mammalian test systems. Environ Toxicol Chem 35:2806-2816.

7. Autrup H, Barile FA, Blaauboer BJ, Degen GH, Dekant W, Dietrich D, Domingo JL, Batta Gori G, Greim H, Hengstler JG, Kacew S, Marquardt H, Pelkonen O, Savolainen K, Vermeulen NP (2015) Principles of pharmacology and toxicology also govern effects of chemicals on the endocrine system. Toxicol Sci doi:10.1093/toxsci/kfv082.

8. Balbi T, Ciacci C, Canesi L (2019) Estrogenic compounds as exogenous modulators of physiological functions in molluscs: signaling pathways and biological responses. Comp Biochem Physiol Part C 222:135-144.

9. Becker RA, Ankley GT, Edwards SW, Kennedy S, Linkov I, Meek B, Sachana M, Segner H, Van Der Burg B, Villeneuve DL, Watanabe H, Barton-Maclaren TS (2015) Increasing scientific confidence in Adverse Outcome Pathways: application of tailored Bradford-Hill considerations for evaluating weight of evidence. Reg Toxicol Pharmacol 72:514-37.

10. Bergkamp L (2016) The concept of risk society as a model for risk regulation - its hidden and not so hidden ambitions, side effects, and risks. J Risk Res 20:1275-1291.

11. Bergman Å, Andersson A-M, Becher G, van den Berg M, Blumberg B, Bjerregaard P, Bornehag C-G, Bornman R, Brandt I, Brian JV, Casey SC, Fowler PA, Frouin H, Giudice LC, Iguchi T, Hass U, Jobling S, Juul A, Kidd KA, Kortenkamp A, Lind M, Martin OV, Muir D, Ochieng R, Olea N, Norrgren L, Ropstad E, Ross PS, Rudén C, Scheringer M, Skakkebaek NE, Söder O, Sonnenschein C, Soto A, Swan S, Toppari J, Tyler CR, Vandenberg LN, Vinggaard AM, Wiberg K, Zoeller RT (2013a) Science and policy on endocrine disrupters must not be mixed: a reply to a "common sense" intervention by toxicology journal editors. Environ Health 12:69.

12. Bergman Å, Heindel JJ, Jobling S, Kidd KV, Zoeller RT (eds) (2013b) State of the Science of Endocrine Disrupting Chemicals - 2012. UNEP and WHO, Geneva, Switzerland.

13. Billas IML, Browning C, Lawrence MC, Graham LD, Moras D, Hill RJ (2009) The structure and function of ecdysone receptors. In: Smagghe G. (ed) Ecdysone: Structures and Functions. Springer, Dordrecht.

14. Bopp S, Nepelska M, Halder M, Munn S (2017) Expert survey on identification of gaps in available test methods for evaluation of endocrine disruptors; JRC Technical Report, EUR 28592 EN, Luxembourg.

15. Breitholtz M (2013) Crustaceans. In: Matthiessen P (ed) Endocrine Disrupters: Hazard Testing And Assessment Methods. John Wiley \& Sons, Hoboken, NJ. pp 116-142. 
16. Brockmeier EK, Hodges G, Hutchinson TH, Butler E, Hecker M, Tollefsen KE, Garcia-Reyero N, Kille P, Becker D, Chipman K (2017) The role of omics in the application of Adverse Outcome Pathways for chemical risk assessment. Toxicol Sci 158:252-262.

17. Browne P, Noyes PD, Casey WM, Dix DJ (2017) Application of Adverse Outcome Pathways to U.S. EPA's Endocrine Disruptor Screening Program. Environ Health Perspect 096001-1-11.

18. Browne P, Van Der Wal L, Gourmelon A (2020) OECD approaches and considerations for regulatory evaluation of endocrine disruptors. Mol Cell Endocrinol 15:504:110675.

19. Budd GE, Mann RP (2020) The dynamics of stem and crown groups. Sci. Adv. 6: eaaz1626.

20. Carss DN, Brito AC, Chainho P, Ciutat A, de Montaudouin X, Otero RMF, Filgueira MI, Garbutt A, Goedknegt MA, Lynch SA, Mahony KE, Maire O, Malham SK, Orvain F, van der Schatte Olivier A, Jones L (2020) Ecosystem services provided by a non-cultured shellfish species: The common cockle Cerastoderma edule. Mar Environ Res 158 (2020) 104931.

21. Castro LFC, Santos MM (2014) "To bind or not to bind": the taxonomic scope of nuclear receptor mediated endocrine disruption in invertebrate phyla. Environ Sci Technol 48:5361-5363.

22. Chapman AD (2009) Numbers of Living Species in Australia and the World, 2nd edition. Report for the Australian Biological Resources Study, Canberra, Australia September 2009.

23. Cherbas L, Koehler MMD, Cherbas P (1989) Effects of juvenile hormone on the ecdysone response of Drosophila Kc cells. Dev Genetics 10:177-188.

24. Coady KK, Biever RC, Denslow ND, Gross M, Guiney PD, Holbech H, Karouna-Renier NK, Katsiadaki I, Krueger H, Levine SL, Maack G, Williams M, Wolf JC, Ankley GT (2017) Current limitations and recommendations to improve testing for the environmental assessment of endocrine active substances. Integr Environ Assess Manag 13:302-316.

25. Collen B, Böhm M, Kemp R, Baillie JEM (2012) Spineless: status and trends of the world's invertebrates. Zoological Society of London, United Kingdom.

26. Conolly RB, Ankley GT, Cheng WY, Mayo ML, Miller DH, Perkins EJ, Villeneuve DL, Watanabe KH (2017) Quantitative Adverse Outcome Pathways and their application to predictive toxicology. Environ Sci Technol 51:4661-4672.

27. Crane M, Hallmark N, Lagadic L, Ott K, Pickford D, Preuss T, Thompson H, Thorbek P, Weltje L, Wheeler JR (2019a) Establishing the relevance of endocrinedisrupting effects for nontarget vertebrate populations. Integr Environ Assess Manag 15:299-301.

28. Crane M, Hallmark N, Lagadic L, Ott K, Pickford D, Preuss T, Thompson H, Thorbek P, Weltje L, Wheeler JR (2019b) Assessing the population relevance of endocrine-disrupting effects for nontarget vertebrates exposed to plant protection products. Integrr Environ Assess Manag 15:278-291.

29. Crane M, Norton A, Leaman J, Chalak A, Bailey A, Yoxon M, Smith J, Fenlon (2006) Acceptability of pesticide impacts on the environment: what do United Kingdom stakeholders and the public value? Pest Man Sci 62:5-19.

30. Cuvillier-Hot V, Lenoir A (2020) Invertebrates facing contamination by endocrine disruptors: novel evidences and recent insights. Mol Cell Endocrinology 504:110712.

31. Day P, Green RM, Gross M, Weltje L, Wheeler JR (2018) Endocrine disruption: current approaches for regulatory testing and assessment of plant protection products are fit for purpose. Toxicol Letters 296:10-22.

32. deFur PL (2004) Use and role of invertebrate models in endocrine disruptor research and testing. ILAR J. 45:484-493.

33. deFur PL, Crane M, Ingersoll C, Tattersfield L (eds) (1999) Endocrine Disruption in Invertebrates: Endocrinology, Testing, and Assessment. SETAC Press, Pensacola, FL.

34. Derwent Innovation (2021) https://clarivate.com/derwent/solutions/derwent-innovation/. Accessed March 2021.

35. Devillers D, Devillers H (2013) Population dynamics models for assessing the endocrine disruption potential of juvenile hormone analogues on nontarget species. In: Devillers J (ed) Juvenile Hormones and Juvenoids: Modeling Biological Effects and Environmental Fate, CRC Press, Boca Raton, FL pp. 127144.

36. Devillers J, Devillers H, Decourtye A, Fourrier J, Aupinel P, Fortini D (2014) Agent-based modeling of the long-term effects of pyriproxyfen on honeybee population. In: Devillers J (ed.) In Silico Bees, CRC Press, Boca Raton, FL.

37. Dhadialla TS (ed) (2012) Insect Growth Disruptors. Advances in Insect Physiology 43:1-552.

38. Dietrich DR, von Aulock S, Marquardt H, Blaauboer B, Dekant W, Kehrer J, Hengstler J, Collier A, Batta Gori G, Pelkonen O, Lang F, Barile FA, Nijkamp FP, Stemmer K, Li A, Savolainen K, Hayes AW, Gooderham N, Harvey A (2013) Scientifically unfounded precaution drives European Commission's recommendations on EDC regulation, while defying common sense, well-established science and risk assessment principles. Chemico-Biological Interactions 5;205(1):A1-5.

39. Dinan L, Bourne P, Whiting P, Dhadialla TS, Hutchinson TH (2001) Screening of environmental contaminants for ecdysteroid agonist and antagonist activity using the Drosophila melanogaster B-II cell in vitro assay. Environ Toxicol Chem 20:2038-2046.

40. Ducrot V, Péry ARR, Lagadic L (2010a) Modelling effects of diquat under realistic exposure patterns in genetically differentiated populations of the gastropod Lymnaea stagnalis. Phil Trans R Soc B 365:3485-3494.

41. Ducrot V, Teixeira-Alves M, Lopes C, Delignette-Muller M-L, Charles S, Lagadic L (2010b) Development of partial life-cycle experiments to assess the effects of endocrine disruptors on the freshwater gastropod Lymnaea stagnalis: a case-study with vinclozolin. Ecotoxicology 19:1312-1321.

42. Duft M, Schmitt C, Bachmann J, Brandelik C, Schulte-Oehlmann U, Oehlmann J (2007) Prosobranch snails as test organisms for the assessment of endocrine active chemicals - an overview and a guideline proposal for a reproduction test with the freshwater mudsnail Potamopyrgus antipodarum. Ecotoxicology 16:169-182.

43. Dumollard R, Gazo I, Gomes IDL, Besnardeau L, McDougall A (2017) Ascidians: an emerging marine model for drug discovery and screening. Curr Top Med Chem 17:2056-2066. 
44. [EC] European Commission (2000) Communication from the Commission on the precautionary principle. Commission of the European Communities, Brussels, Belgium, 2.2.2000 $\operatorname{COM}(2000) 1$ final.

45. [EC] European Commission (2012) LIFE and invertebrate conservation. Publications Office of the European Union, Luxembourg.

46. [EC] European Commission (2018a) Communication from the Commission to the European Parliament, the Council, the European Economic and Social Committee and the Committee of the Regions. Towards a comprehensive European Union framework on endocrine disruptors. European Commission, Brussels, Belgium, 7.11.2018 COM(2018) 734 final.

47. [EC] European Commission (2018b) Setting priorities for further development and validation of test methods and testing approaches for evaluating endocrine disruptors. Final Report. Luxembourg.

48. [EC] European Commission (2018c) Commission Regulation (EU) 2018/605 of 19 April 2018 amending Annex II to Regulation (EC) No 1107/2009 by setting out scientific criteria for the determination of endocrine disrupting properties. OJ L 101/33. 2018 Apr 20.

49. [ECETOC] European Centre for Ecotoxicology and Toxicology of Chemicals (2016) Guidance on Assessment and Application of Adverse Outcome Pathways (AOPs) Relevant to the Endocrine System, Technical Report No. 128, Brussels, December 2016.

50. [ECHA/EFSA] European Chemicals Agency, European Food Safety Authority [with the technical support of the Joint Research Centre (JRC)] (2018) Guidance for the identification of endocrine disruptors in the context of Regulations (EU)No528/2012 and (EC)No1107/2009. EFSA J 16(6):5311.

51. Edwards SW, Tan Y-M, Villeneuve DL, Meek ME, McQueen CA (2016) Adverse Outcome Pathways-Organizing Toxicological Information to Improve Decision Making. J Pharmacol Exp Ther 356:170-81.

52. [EFSA] European Food Safety Authority (2010) Report on the PPR stakeholder workshop protection goals for environmental risk assessment of pesticides: What and where to protect? EFSA J 8:1672.

53. [EFSA] European Food Safety Authority (2019) Conclusion on the peer review of the pesticide risk assessment of the active substance pyriproxyfen. EFSA $\mathrm{J}$ 17:5732.

54. [EFSA SC] European Food Safety Authority Scientific Committee (2013) Scientific Opinion on the hazard assessment of endocrine disruptors: scientific criteria for identification of endocrine disruptors and appropriateness of existing test methods for assessing effects mediated by these substances on human health and the environment. EFSA J 11:3132.

55. [EFSA SC] European Food Safety Authority Scientific Committee (2016) Guidance to develop specific protection goals options for environmental risk assessment at EFSA, in relation to biodiversity and ecosystem services. EFSA J 14:4499.

56. [EFSA SC] European Food Safety Authority Scientific Committee (2017) Scientific opinion on guidance on the assessment of the biological relevance of data in scientific assessments. EFSA J 15:4970.

57. Erwin DH, Laflamme M, Tweedt SM, Sperling EA, Pisani D, Peterson KJ (2011) The Cambrian conundrum: early divergence and later ecological success in the early history of animals. Science 334:1091-1097.

58. Erwin DH (2015) Early metazoan life: divergence, environment and ecology. Phil Trans R Soc B 370: 20150036.

59. Fay KA, Villeneuve CADL, LaLone YCA, Song K-EY, Tollefsen K-E., Ankley GT (2017) Practical approaches to adverse outcome pathway (AOP) development and weight-of-evidence evaluation as illustrated by ecotoxicological case studies. Environ Toxicol Chem 36:1429-1449.

60. Fernandes D, Loi B, Porte C (2011) Biosynthesis and metabolism of steroids in molluscs. J Steroid Biochem Mol Biol 127:189-195.

61. Fernández-González LE, Diz AP, Grueiro NG, Muniategui-Lorenzo S, Beiras R, Sánchez-Marín P (2020) No evidence that vitellogenin protein expression is induced in marine mussels after exposure to an estrogenic chemical. Sci Total Environ 721:137638.

62. Filer D, Patisaul HB, Schug T, Reif D, Thayer K (2014) Test driving ToxCast: endocrine profiling for 1858 chemicals included in phase II. Curr Opinion Pharmacol 19:145-152.

63. Fodor I, Urbán P, Scott AP, Pirger Z (2020) A critical evaluation of some of the recent so-called 'evidence' for the involvement of vertebrate-type sex steroids in the reproduction of mollusks. Mol Cell Endocrinol 516:110949.

64. Forbes VE, Olsen M, Palmqvist A, Calow P (2010) Environmentally sensitive life-cycle traits have low elasticity: implications for theory and practice. Ecol Appl 20:1449-1455.

65. Forbes VE, Galic N, Schmolke A, Vavra J, Pastorok R, Thorbek P (2016) Assessing the risks of pesticides to threatened and endangered species using population modeling: a critical review and recommendations for future work. Environ Toxicol Chem 35:1904-1913.

66. Forbes VE, Salice C.J., Birnir B, Bruins RJF, Calow P, Ducrot V, Galic N, Garber K, Harvey BC, Jager H, Karanek A, Pastorok R, Railsback SF, Rebarber R, Thorbek P (2017) A framework for predicting impacts on ecosystem services from (sub)organismal responses to chemicals. Environ Toxicol Chem 36:845-859.

67. Ford AT, LeBlanc GA (2020) Endocrine disruption in invertebrates: a survey of research progress. Environ Sci Technol 54:13365-13369.

68. Fourrier J, Deschamps M, Droin L, Alaux C, Fortini D, Beslay D, Le Conte Y, Devillers J, Aupinel P, Decourtye A (2015) Larval exposure to the juvenile hormone analog pyriproxyfen disrupts acceptance of and social behavior performance in adult honeybees. PLoS ONE 10(7): e0132985.

69. Giacomotto J, Ségalat L (2010) High-throughput screening and small animal models, where are we? Br J Pharmacol 160:204-216.

70. Godfray HCJ, Stephens AEA, Jepson PD, Jobling S, Johnson AC, Matthiessen P, Sumpter JP, Tyler CR, McLean AR (2019) A restatement of the natural science evidence base on the effects of endocrine disrupting chemicals on wildlife. Proc R Soc B 286:20182416.

71. Gunnarsson L, Jauhiainen A, Kristiansson E, Nerman O, Larsson DGJ (2008) Evolutionary conservation of human drug targets in organisms used for environmental risk assessments. Environ Sci Technol 42:5807-5813. 
72. Hallmann CA, Sorg M, Jongejans E, Siepel H, Hofland N, Schwan H, Stenmans W, Müller A, Sumser H, Hörren T, Goulson D, de Kroon H (2017) More than 75 percent decline over 27 years in total flying insect biomass in protected areas. PLoS ONE 12(10): e0185809.

73. Hannas BR, Wang YH, Thomson S, Kwon G, Li H, LeBlanc GA (2011) Regulation and dysregulation of vitellogenin mRNA accumulation in daphnids (Daphnia magna). Aquat Toxicol 101:351-357.

74. Hartung T, De Vries R, Hoffmann S, Hogberg HT, Smirnova L, Tsaioun K, Whaley P, Leist M (2019) Toward good in vitro reporting standards. ALTEX 36:317.

75. Hayhow DB, Eaton MA, Stanbury AJ, Burns F, Kirby WB, Bailey, Beckmann B, Bedford J, Boersch-Supan PH, Coomber F, Dennis EB, Dolman SJ, Dunn E, Hall J, Harrower C, Hatfield JH, Hawley J, Haysom K, Hughes J, Johns DG, Mathews F, McQuatters-Gollop A, Noble DG, Outhwaite CL, Pearce-Higgins JW, Pescott OL, Powney GD, Symes N (2019) State of Nature 2019. State of Nature Partnership (UK), 107pp.

76. Hecker M (2018) Non-model species in ecological risk assessment. In: Garcia-Reyero N, Murphy CA (eds) A Systems Biology Approach to Advancing Adverse Outcome Pathways for Risk Assessment. Springer International Publishing, pp 107- 132.

77. Hecker M, LaLone CA (2019) Adverse Outcome Pathways: moving from a scientific concept to an internationally accepted framework. Environ Toxicol Chem 38:1152-1163.

78. Hill RL (1997) Incorporating toxic disturbance effects into a population model of a crustacean fishery. Proc Gulf Caribb Fish Inst 49:139-155.

79. Hodges G, Gutsell S, Taylor N, Brockmeier E, Butler E, Rendal C, Colbourne J (2018) Invertebrate Model Species in AOP Development. In: Garcia-Reyero N, Murphy CA (eds.) A Systems Biology Approach to Advancing Adverse Outcome Pathways for Risk Assessment. Springer International Publishing, pp 75106.

80. Hommen U, Forbes V, Grimm V, Preuss TG, Thorbek P, Ducrot V (2015) How to use mechanistic effect models in environmental risk assessment of pesticides: case studies and recommendations from the SETAC workshop MODELINK. Integr Environ Assess Manag 12:21-31.

81. Höss S, Weltje L (2007) Endocrine disruption in nematodes: effects and mechanisms. Ecotoxicology 16:15-28.

82. Houck KA, Simha A, Bone A, Doering JA, Vliet SMF, LaLone C, Medvedev A, Makarov S (2021) Evaluation of a multiplexed, multispecies nuclear receptor assay for chemical hazard assessment. Toxicol in Vitro 72:105016.

83. Howe PL, Reichelt-Brushett AJ, Clark MW (2012) Aiptasia pulchella: a tropical cnidarian representative for laboratory ecotoxicological research. Environ Tox Chem 34:2653-2662.

84. Howe PL, Reichelt-Brushett AJ, Clark MW (2014) Development of a chronic, early life-stage sub-lethal toxicity test and recovery assessment for the tropical zooxanthellate sea anemone Aiptasia pulchella. Ecotoxicol Environ Saf 100:138-147.

85. Howe PL, Reichelt-Brushett AJ, Krassoi R, Micevska T (2015) Comparative sensitivity of the cnidarian Exaiptasia pallida and a standard toxicity test suite: testing whole effluents intended for ocean disposal. Environ Sci Pollut Res Int 22:13225-13233.

86. Hutchinson TH (2007) Small is useful in endocrine disrupter assessment - four key recommendations for aquatic invertebrate research. Ecotoxicology 16:231-238.

87. Janer G, Porte C (2007) Sex steroids and potential mechanisms of non-genomic endocrine disruption in invertebrates. Ecotoxicology 16:145-160.

88. Jin S, Yang F, Liao T, Hui Y, Wen S, Xu Y (2012) Enhanced effects by mixtures of three estrogenic compounds at environmentally relevant levels on development of Chinese rare minnow (Gobiocypris rarus). Environ Toxicol Pharmacol 33:277-283.

89. Jindra M (2021) New ways and new hopes for IGR development. J Pestic Sci 46:3-6.

90. Jindra M, Bittova L (2020) The juvenile hormone receptor as a target of juvenoid "insect growth regulators". Arch Insect Biochem Physiol $103(3)$ e21615.

91. Judson R, Houck K, Watt E, Thomas RS (2017) On selecting a minimal set of in vitro assays to reliably determine estrogen agonist activity. Regul Toxicol Pharmacol 91:39-49.

92. Katsiadaki I (2019) Are marine invertebrates really at risk from endocrine-disrupting chemicals? Curr Opinion Environ Sci Health 11:37-42.

93. Kaur P, Singh A, Chana I (2021) Computational techniques and tools for omics data analysis: state-of-the-art, challenges, and future directions. Arch Computat Methods Eng 28:4595-4631.

94. Kavlock R, Chandler K, Houck K, Hunter S, Judson R, Kleinstreuer N, Knudsen T, Martin M, Padilla S, Reif D, Richard A, Rotroff D, Sipes N, Dix D (2012) Update on EPA's ToxCast program: providing high throughput decision support tools for chemical risk management. Chem Res Toxicol 25:1287302.

95. Khammash M (2018) Reverse engineering: the architecture of biological networks. BioTechniques 44:323-328.

96. Knapen D, Angrish MM, Fortin MC, Katsiadaki I, Leonard M, Margiotta-Casaluci L, Munn S, O'Brien JM, Pollesch N, Smith LC, Zhang X, Villeneuve DL (2018) Adverse outcome pathway networks I: development and applications. Environ Toxicol Chem 37:1723-1733.

97. Knigge T, LeBlanc GA, Ford AT (2021) A crab is not a fish: unique aspects of the crustacean endocrine system and considerations for endocrine toxicology. Front Endocrinol 12:587608.

98. Köhler H-R, Kloas W, Schirling M, Lutz I, Reye AL, Langen J-S, Triebskorn R, Nagel R, Schönfelder (2007) Sex steroid receptor evolution and signalling in aquatic invertebrates. Ecotoxicology 16:131-143.

99. Kostich MS, Lazorchak JM (2008) Risks to aquatic organisms posed by human pharmaceutical use. Sci Total Environ 389:329-339.

100. Kramer VJ, Etterson MA, Hecker M, Murphy CA, Roesijadi G, Spade DJ, Spromberg JA, Wang M, Ankley GT (2011) Adverse outcome pathways and ecological risk assessment: bridging to population-level effects. Environ Toxicol Chem 30:64-76.

101. Kubickova B, Ramwell C, Hilscherova K, Jacobs MN (2021) Highlighting the gaps in hazard and risk assessment of unregulated Endocrine Active Substances in surface waters: retinoids as a European case study. Environ Sci Eur 33, 20 (2021).

Page $17 / 28$ 
102. Kuhn A, Munns WR Jr., Poucher S, Champlin D, Lussier S (2009) Prediction of population-level response from mysid toxicity test data using population modeling techniques. Environ Toxicol Chem 19:2364-2371.

103. Kusk KO, Wollenberger L (2007) Towards an internationally harmonized test method for reproductive and developmental effects of endocrine disrupters in marine copepods. Ecotoxicology 16:183-195.

104. LaFont $R$ (2000) The endocrinology of invertebrates. Ecotoxicology 9:41-57.

105. Lagadic L, Coutellec M-A, Caquet T (2007) Endocrine disruption in aquatic pulmonated molluscs: few evidences, many challenges. Ecotoxicology 16:4559 .

106. Lagadic L, Katsiadaki I, Biever R, Guiney PD, Karouna-Renier N, Schwarz T, Meador JP (2017) Tributyltin: Advancing the Science on Assessing Endocrine Disruption with an Unconventional Endocrine-Disrupting Compound. In: de Voogt P. (ed.) Rev Environ Contam Toxicol 245. Springer, Cham. pp 65-127.

107. Lagadic L, Wheeler JR, Weltje L (2020) (Mis)use of the Adverse Outcome Pathway concept for assessing endocrine disruption in nontarget organisms. Integr Environ Assess Manag 16:525-530.

108. LaLone CA, Villeneuve DL, Burgoon LD, Russom CL, Helgen HW, Berninger JP, Tietge JE, Severson MN, Cavallin JE, Ankley GT (2013a) Molecular target sequence similarity as a basis for species extrapolation to assess the ecological risk of chemicals with known modes of action. Aquat Toxicol 144/145:141-154.

109. LaLone CA, Villeneuve DL, Cavallin JE, Kahl MD, Durhan EJ, Makynen EA, Jensen KM, Stevens KE, Severson MN, Blanksma CA, Flynn KM, Hartig PC, Woodard JS, Berninger JP, Norberg-King TJ, Johnson RD, Ankley GT (2013b) Cross-species sensitivity to a novel androgen receptor agonist of potential environmental concern, spironolactone. Environ Toxicol Chem 32:2528-41.

110. Lalone CA, Berninger JP, Villeneuve DL, Ankley GT (2014) Leveraging existing data for prioritization of the ecological risks of human and veterinary pharmaceuticals to aquatic organisms. Phil Trans R Soc B 369:20140022.

111. LaLone CA, Villeneuve DL, Lyons D, Helgen HW, Robinson SL, Swintek JA, Saari TW, Ankley GT (2016) Editor's highlight: Sequence Alignment to Predict Across Species Susceptibility (SeqAPASS): A web-based tool for addressing the challenges of cross-species extrapolation of chemical toxicity. Toxicol Sci 153:228-245.

112. LaLone C, Villeneuve DL, Doering JA, Blackwell BR, Transue TR, Simmons CW, Swintek J, Degitz SJ, Williams AJ, Ankley GT (2018) Evidence for cross species extrapolation of mammalian-based high-throughput screening assay results. Environ Sci Technol 52:13960-13971.

113. Langston W (2020) Endocrine disruption and altered sexual development in aquatic organisms: An invertebrate perspective. J Mar Biol Assoc UK 100:495515.

114. Leonard J, Bell S, Oki N, Nelms M, Tan Y-M, Edwards S (2018) Tiered Approaches to Incorporate the Adverse Outcome Pathway Framework into ChemicalSpecific Risk-Based Decision Making. In: Garcia-Reyero N, Murphy CA (eds) A Systems Biology Approach to Advancing Adverse Outcome Pathways for Risk Assessment. Springer International Publishing, pp 235-261.

115. LeBlanc GA (2007) Crustacean endocrine toxicology: a review. Ecotoxicology 16:61-81.

116. Madden JC, Rogiers V, Vinken M (2014) Application of in silico and in vitro methods in the development of adverse outcome pathway constructs in wildlife. Philos Trans R Soc Lond B Biol Sci 369(1656).

117. Marty S, Borgert C, Coady K, Green R, Levine SL, Mihaich E, Ortego L, Wheeler JR, Yi KD, Zorrilla LM (2018) Distinguishing between endocrine disruption and non-specific effects on endocrine system. Reg Toxicol Pharmacol 99:142-158.

118. Martyniuk CJ, Simmons DB (2016) Spotlight on environmental omics and toxicology: a long way in a short time. Comp Biochem Physiol D 19:97-101.

119. Matthiessen $P$ (2008) An assessment of endocrine disruption in mollusks and the potential for developing internationally standardized mollusk life cycle test guidelines. Integr Environ Assess Manag 4:274-284.

120. Matthiessen PG, Ankley R, Biever P, Bjerregaard C, Borgert K, Brugger A, Blankinship J, Chambers K, Coady L, Constantine Z, Dang Z, Denslow ND, Dreier DA, Dungey S, Gray LE, Gross M, Guiney PD, Hecker M, Holbech H, Iguchi T, Kadlec S, Karouna-Renier NK, Katsiadaki I, Kawashima Y, Kloas W, Krueger H, Kumar A, Lagadic L, Leopold A, Levine SL, Maack G, Marty S, Meador J, Mihaich E, Odum J, Ortego L, Parrott J, Pickford D, Roberts M, Schaefers C, Schwarz T, Solomon K, Verslycke T, Weltje L, Wheeler JR, Williams M, Wolf JC, Yamazaki K (2017) Recommended approaches to the scientific evaluation of ecotoxicological hazards and risks of endocrine-active substances. Integr Environ Assess Manag 13:267-269.

121. Matthiessen P, Wheeler JR, Weltje L (2018) A review of the evidence for endocrine disrupting effects of current-use chemicals on wildlife populations. Crit Rev Toxicol 48:195-216.

122. McBride MT (2018) The application of omics data to the development of AOPs. In: Garcia-Reyero N, Murphy CA (eds) A Systems Biology Approach to Advancing Adverse Outcome Pathways for Risk Assessment. Springer International Publishing, pp 177-198.

123. McClellan-Green PD (2013) Endocrine disruption in molluscs: processes and testing. In: Matthiessen P (ed) Endocrine Disrupters: Hazard Testing and Assessment Methods. John Wiley \& Sons, Hoboken, NJ. pp 143-184.

124. Mellor CL, Tollefsen KE, LaLone C, Cronin MTD, Firman JW (2020) In silico identification of chemicals capable of binding to the ecdysone receptor. Environ Toxicol Chem 39:1438-1450.

125. Mihaich EM, Schäfers C, Dreier DA, Hecker M, Ortego L, Kawashima Y, Dang Z-C, Solomon K (2017) Challenges in assigning endocrine-specific modes of action: Recommendations for researchers and regulators. Integr Environ Assess Manag 13:280-292.

126. Miyakawa H, Iguchi T (2017) Comparative luciferase assay for establishing reliable in vitro screening system of juvenile hormone agonists. J Appl Toxicol 37:1082-1090.

127. Munn S, Goumenou M (2013) Key scientific issues relevant to the identification and characterisation of endocrine disrupting substances. Report of the Endocrine Disrupters Expert Advisory Group. European Commission Joint Research Centre, Institute for Health and Consumer Protection, Ispra (VA), Italy.

Page 18/28 
128. Noriega JA, Hortal J, Azcárate FM, Berg MP, Bonada N, Briones MJI, Del Toro I, Goulson D, Ibanez S, Landis DA, Moretti M, Potts SG, Slade EM, Stout JC, Ulyshen MD, Wackers FL, Woodcock BA. Santost AMC (2018) Research trends in ecosystem services provided by insects. Basic Appl Ecol 26:8-23.

129. [OECD] Organization for Economic Cooperation and Development (2017) Revised Guidance Document on Developing and Assessing Adverse Outcome Pathways. Series on Testing and Assessment No. 184. ENV/JM/MONO(2013)6. OECD Environment, Health and Safety Publications, Paris, France.

130. [OECD] Organization for Economic Cooperation and Development (2018a) Revised Guidance Document 150 on Standardised Test Guidelines for Evaluating Chemicals for Endocrine Disruption, OECD Series on Testing and Assessment, Paris, France.

131. [OECD] Organization for Economic Cooperation and Development (2018b) Users' handbook supplement to the guidance document for developing and assessing AOPs. Series on Testing \& Assessment No. 233 Series on Adverse Outcome Pathways No. 1. 14 February 2018 update. ENV/JM/MONO(2016)12. Paris, France.

132. [OECD] Organization for Economic Cooperation and Development (2018c) Guidance Document on Good In Vitro Method Practices (GIVIMP), OECD Series on Testing and Assessment, No. 286, OECD Publishing, Paris, France.

133. Oehlmann J, Di Benedetto P, Tillmann M, Duft M, Oetken M, Schulte-Oehlmann U (2007) Endocrine disruption in prosobranch molluscs: evidence and ecological relevance. Ecotoxicology 16:29-43.

134. Oetken M, Bachmann J, Schulte-Oehlmann U, Oehlmann J (2004) Evidence for endocrine disruption in invertebrates. Internat Rev Cytol $236: 1-43$.

135. Oliveira E, Barata C, Piña B (2016) Endocrine disruption in the omics era: new views, new hazards, new approaches. Open Biotech J 10:20-35..

136. Pener MP, Dhadialla TS (2012) Chapter One - An Overview of Insect Growth Disruptors; Applied Aspects. Adv Insect Physiol 43:1-162.

137. Perkins EJ, Ashauer R, Burgoon L, Conolly R, Landesmann B, Mackay C, Murphy CA, Pollesch N, Wheeler JR, Zupanic A, Scholz S (2019a) Building and applying quantitative Adverse Outcome Pathway models for chemical hazard and risk assessment. Environ Toxicol Chem 38:1850-1865.

138. Perkins EJ, Gayen K, Shoemaker JE, Antczak P, Burgoon L, Falciani F, Gutsell S, Hodges G, Kienzler A, Knapen D, McBride M, Willett C, Doyle FJ III, GarciaReyero N (2019b) Chemical hazard prediction and hypothesis testing using quantitative Adverse Outcome Pathways. ALTEX 36:91-102.

139. Perkins EJ, Chipman JK, Edwards S, Habib T, Falciani F, Taylor R, Van Aggelen G, Vulpe C, Antczak P, Loguinov A (2011) Reverse engineering adverse outcome pathways. Environ Toxicol Chem 30:22-38.

140. Pfister CA (1998) Patterns of variance in stage-structured populations: evolutionary predictions and ecological implications. PNAS 95:213-219.

141. Piersma AH, Burgdorf T, Louekari K, Desprez B, Taalman R, Landsiedel R, Barroso J, Rogiers V, Eskes C, Oelgeschläger M, Whelan M, Braeuning A, Vinggaard AM, Kienhuis A, van Benthem J, Ezendam J (2018) Workshop on acceleration of the validation and regulatory acceptance of alternative methods and implementation of testing strategies. Toxicol In Vitro 50:62-74.

142. Quercioli D, Roli A, Morandi E, Perdichizzi S, Polacchini L, Rotondo F, Vaccari M, Villani M, Serra R, Colacci A (2018) The use of omics-based approaches in regulatory toxicology: An alternative approach to assess the no observed transcriptional effect level. Microchem J 136:143-148.

143. Raimondo S, McKenney CL Jr (2005) Projecting population-level responses of mysids exposed to an endocrine disrupting chemical. Integr Comp Biol 45:151-157.

144. Reif DM, Martin MT, Tan SW, Houck KA, Judson RS, Richard AM, Knudsen TB, Dix DJ, Kavlock RJ (2010) Endocrine profiling and prioritization of environmental chemicals using ToxCast data. Environ Health Perspect 118:1714-1720.

145. Rico A, Van den Brink PJ (2015) Evaluating aquatic invertebrate vulnerability to insecticides based on intrinsic sensitivity, biological traits, and toxic mode of action. Environ Toxicol Chem 34:1907-17.

146. Rife GS (2018) Ecosystem services provided by benthic macroinvertebrate assemblages in marine coastal zones. In: Hufnagel L (ed) Ecosystem Services and Global Ecology. IntechOpen DOI: 10.5772/intechopen.73150.

147. Rotroff DM, Dix DJ, Houck KA, Knudsen TB, Martin MT, McLaurin KW, Reif DM, Crofton KM, Singh AV, Xia M, Huang R, Judson RS (2013) Using in vitro High Throughput Screening assays to identify potential endocrine-disrupting chemicals. Environ Health Perspect 121:7-14.

148. Rubach MN, Baird DJ, Van den Brink PJ (2010) A new method for ranking mode-specific sensitivity of freshwater arthropods to insecticides and its relationship to biological traits. Environ Toxicol Chem 29:476-487.

149. Rubach MN, Ashauer R, Buchwalter DB, De Lange HJ, Hamer M, Preuss TG, Töpke K, Maund SJ (2011) Framework for traits-based assessment in ecotoxicology. Integr Environ Assess Manag 7:172-186.

150. Sainath SB, André A, Castro LFC, Santos MM (2019) The evolutionary road to invertebrate thyroid hormone signaling: Perspectives for endocrine disruption processes. Comp Biochem Physiol C 223:124-138.

151. Salzet M (2001) The neuroendocrine system of annelids. Can J Zool 79:175-191.

152. Scott AP (2012) Do mollusks use vertebrate sex steroids as reproductive hormones? I: Critical appraisal of the evidence for the presence, biosynthesis and uptake of steroids. Steroids 77:1450-1468.

153. Scott AP (2013) Do mollusks use vertebrate sex steroids as reproductive hormones? II. Critical review of the evidence that steroids have biological effects. Steroids 78:268-281.

154. Scott AP (2018) Is there any value in measuring vertebrate steroids in invertebrates? Gen Comp Endocrinol 265:77-82.

155. Schroeder AL, Ankley GT, Houck KA, Villeneuve DL (2016) Environmental surveillance and monitoring -the next frontiers for high-throughput toxicology. Environ Toxicol Chem 35:513-25.

156. Schröter M, van der Zanden EH, van Oudenhoven APE, Remme RP, Serna-Chavez HM, de Groot RS, Opdam P (2014) Ecosystem services as a contested concept: a synthesis of critique and counter-arguments. Conservation Letters 7:514-523. 
157. Sewell F, Gellatly N, Beaumont M, Burden N, Currie R, de Haan L, Hutchinson TH, Jacobs M, Mahony C, Malcomber I, Mehta J, Whale G, Kimber I (2018) The future trajectory of adverse outcome pathways: a commentary. Arch Toxicol 92:1657-1661.

158. Short SJ, Yang G, Kille P, Ford AT (2014) Vitellogenin is not an appropriate biomarker of feminisation in a crustacean. Aquat Toxicol 153:89-97.

159. Smagghe G (2008) Ecdysone agonists, a novel group of Insect Growth Regulators. In: Capinera JL (ed) Encyclopedia of Entomology. Springer, Dordrecht.

160. Smagghe G, Braeckman BP, Huys N, Raes H (2003) Cultured mosquito cells Aedes albopictus C6/36 (Dip, Culicidae) responsive to 20-hydroxyecdysone and non-steroidal ecdysone antagonists. J Appl Entomol 127:167-173.

161. Soin T, Smagghe G (2007) Endocrine disruption in aquatic insects: a review. Ecotoxicology 16:83-93.

162. Solecki R, Kortenkamp A, Bergman A, Chahoud I, Degen GH, Dietrich D, Greim H, Håkansson H, Hass U, Husoy T, Jacobs M, Jobling S, Mantovani A, Marx-Stoelting P, Piersma A, Ritz V, Slama R, Stahlmann R, van den Berg M, Zoeller RT, Boobis AR (2017) Scientific principles for the identification of endocrine-disrupting chemicals: a consensus statement. Arch Toxicol 91:1001-1006.

163. Somerfield PJ (2011) Marine and estuarine invertebrates. UK National Ecosystem Assessment: Technical Report, UNEP-WCMC, Cambridge pp 91-92.

164. Song Y, Villeneuve DL, Toyota K, Iguchi T, Tollefsen KE (2017) Ecdysone receptor agonism leading to lethal molting disruption in arthropods: review and Adverse Outcome Pathway development. Environ Sci Technol 51:4142-4157.

165. Sugni M, Mozzi D, Barbaglio A, Bonasoro F, Carnevali MDC (2007) Endocrine disrupting compounds and echinoderms: new ecotoxicological sentinels for the marine ecosystem. Ecotoxicology 16:95-108.

166. Swevers L, Kravariti L, Ciolfi S, Xenou-Kokoletsi M, Ragoussis N, Smagghe G, Nakagawa Y, Mazomenos B, latrou K (2003) A high-throughput screening system for fast detection of ecdysteroid mimetic and antagonistic substances using transformed Bombyx mori derived cell lines. FASEB J 18:134-136.

167. Takahashi T (2020) Comparative aspects of structure and function of cnidarian neuropeptides. Front Endocrinol 11:339.

168. Tanaka Y (2003) Ecological risk assessment of pollutant chemicals: extinction risk based on population-level effects. Chemosphere 53:421-425.

169. Tarrant AM (2007) Hormonal signaling in cnidarians: do we understand the pathways well enough to know whether they are being disrupted? Ecotoxicology 16:5-13.

170. Tatarazako N, Oda S (2007) The water flea Daphnia magna (Crustacea, Cladocera) as a test species for screening and evaluation of chemicals with endocrine disrupting effects on crustaceans. Ecotoxicology 16:197-203.

171. Taylor E, Heyland A (2017) Evolution of thyroid hormone signaling in animals: Non-genomic and genomic modes of action. Mol Cell Endocrinol 459:1420.

172. Thomas RS, Cheung R, Westphal M, Krewski D, Andersen ME (2017) Risk science in the 21 st century: a data-driven framework for incorporating new technologies into chemical safety assessment. Int J Risk Assess Manag 20:88-108.

173. Thompson HM, Wilkins S, Battersby AH, Waite RJ, Wilkinson D (2007) Modelling long-term effects of IGRs on honeybee colonies. Pest Manag Sci 63:1081-1084.

174. Tran TKA, Yu RMK, Islam R, Nguyen THT, Bui TLH, Kong RYC, O'Connor WA, Leusch FDL, Andrew-Priestley M, MacFarlane GR (2019) The utility of vitellogenin as a biomarker of estrogenic endocrine disrupting chemicals in molluscs. Environ Pollut 248:1067e1078.

175. [USEPA] United States Environmental Protection Agency (2017) Continuing development of alternative high-throughput screens to determine endocrine disruption, focusing on androgen receptor, steroidogenesis, and thyroid pathways. White paper developed for the FIFRA SAP, November 28-30, 2017. 159 p. https://www.epa.gov/sap/meeting-materials-november-28-30-2017-scientific-advisory-panel

176. Van Aggelen G, Ankley GT, Baldwin WS, Bearden DW, Benson WH, Chipman JK, Collette TW, Craft JA, Denslow ND, Embry MR, Falciani F, George SG, Helbing CC, Hoekstra PF, Iguchi T, Kagami Y, Katsiadaki I, Kille P, Liu L, Lord PG, Mclntyre T, O'Neill A, Osachoff H, Perkins EJ, Santos EM, Skirrow RC, Snape JR, Tyler CR, Versteeg D, Viant MR, Volz DC, Williams TD, Yu L (2010) Integrating omic technologies into aquatic ecological risk assessment and environmental monitoring: hurdles, achievements, and future outlook. Environ Health Perspect 118:1-5.

177. Van den Berg SJP, Baveco H, Butler E, De Laender F, Focks A, Franco A, Rendal C, Van den Brink PJ (2019) Modeling the sensitivity of aquatic macroinvertebrates to chemicals using traits. Environ Sci Technol 53:6025-6034.

178. Van der Schatte Olivier A, Jones L, Le Vay L, Christie M, Wilson J, Malham SK (2020) A global review of the ecosystem services provided by bivalve aquaculture. Rev Aquaculture 12:3-25.

179. Verslycke T, Ghekiere A, Raimondo S, Janssen C (2007) Mysid crustaceans as standard models for the screening and testing of endocrine-disrupting chemicals. Ecotoxicology 16:205-219.

180. Villaverde AF, Banga JR (2014) Reverse engineering and identification in systems biology: strategies, perspectives and challenges. J R Soc Interface $11: 20130505$.

181. Villeneuve DL, Angrish MM, Fortin MC, Katsiadaki I, Leonard M, Margiotta-Casaluci L, Munn S, O'Brien JM, Pollesch N, Smith LC, Zhang X, Knapen D (2018) Adverse outcome pathway networks Il: Network analytics. Environ Toxicol Chem 37:1734-1748.

182. Villeneuve DL, Crump D, Garcia-Reyero N, Hecker M, Hutchinson TH, LaLone CA, Landesmann B, Lettieri T, Munn S, Nepelska M (2014a) Adverse Outcome Pathway (AOP) development I: strategies and principles. Toxicol Sci 142:312-320.

183. Villeneuve DL, Crump D, Garcia-Reyero N, Hecker M, Hutchinson TH, LaLone CA, Landesmann B, Lettieri T, Munn S \& Nepelska M (2014b) Adverse Outcome Pathway development II: best practices. Toxicol Sci 142:321-330.

184. Vinken M (2019) Omics-based input and output in the development and use of adverse outcome pathways. Curr Opinion Toxicol 18:8-12.

185. Vogeler S, Galloway TS, Isupov M, Bean TP (2017) Cloning retinoid and peroxisome proliferator-activated nuclear receptors of the Pacific oyster and in silico binding to environmental chemicals. PLoS ONE 12(4):e0176024.

Page 20/28 
186. Watt A, Vanbergen A, Keith A (2011) Terrestrial and freshwater invertebrates. UK National Ecosystem Assessment: Technical Report, UNEP-WCMC, Cambridge pp 92-93.

187. Weltje L (2013) Techniques for measuring endocrine disruption in insects. In: Matthiessen P (ed) Endocrine Disrupters: Hazard Testing and Assessment Methods. John Wiley \& Sons, Hoboken, NJ. pp 100-115.

188. Weltje L, Schulte-Oehlmann U (2007) The seven-year itch - progress in research in research on endocrine disruption in aquatic invertebrates since 1999. Ecotoxicology 16:1-3.

189. Wheeler JR, Weltje L (2015) In response: Adverse outcome pathways-An industry perspective. Environ Toxicol Chem 34:1937-1938.

190. WHO-IPCS [World Health Organisation International Programme on Chemical Safety] (2002) Global Assessment of the State-of-the-Science of Endocrine Disruptors. World Health Organisation, Geneva, Switzerland.

191. Wittwehr C, Aladjov H, Ankley GT, Byrne HJ, de Knecht J, Henzie E, Klambauer G, Landesmann B, Luijten M, MacKay C, Maxwell G, Meek ME, Paini A, Perkins E, Sobanski T, Villeneuve D, Waters KM, Whelan M (2017) How adverse outcome pathways can aid the development and use of computational prediction models for regulatory toxicology. Toxicol Sci 155:326-336.

192. Zimmer El, Jager T, Ducrot V, Lagadic L, Koojman SALM (2012) Juvenile food limitation in standardized tests: a warning to ecotoxicologists. Ecotoxicology 21:2195-2204.

193. Zimmer El, Ducrot V, Jager T, Koene J, Lagadic L, Koojman SALM (2014) Metabolic acceleration in the pond snail Lymnaea stagnalis. J Sea Res 94:8491.

194. Zoeller RT, Bergman A, Becher G, Bjerregaard P, Bornman R, Brandt I, Iguchi T, Jobling S, Kidd KA, Kortenkamp A, Skakkebaek NE, Toppari J, Vandenberg LN (2014) A path forward in the debate over health impacts of endocrine disrupting chemicals. Environl Health 13:118.

\section{Tables}

Table 1 Internationally accepted invertebrate toxicity test guidelines. OECD CF level refers to the OECD Conceptual Framework (OECD 2018a). Endpoints in bold are more indicative of a potential ED mode of action. 


\begin{tabular}{|c|c|c|c|c|}
\hline $\begin{array}{l}\text { Invertebrate } \\
\text { group }\end{array}$ & Test Guideline & $\begin{array}{l}\text { OECD } \\
\text { CF } \\
\text { level }\end{array}$ & Endpoints & Comment \\
\hline \multirow[t]{2}{*}{ Crustacea } & $\begin{array}{l}\text { Short-Term Juvenile Hormone Activity } \\
\text { Screening Assay using }\end{array}$ & 3 & Production of male neonates & Under development \\
\hline & Daphnia magna (SJHASA) (draft OECD TG) & & & \\
\hline \multirow[t]{5}{*}{ Crustacea } & \multirow{5}{*}{$\begin{array}{l}\text { OECD TG 211/OCSPP 850.1300: Daphnia } \\
\text { magna Reproduction Test (with potential } \\
\text { male induction assessed) }\end{array}$} & \multirow[t]{5}{*}{4} & & \multirow{5}{*}{$\begin{array}{l}\text { Male production is known in response to } \\
\text { juvenile hormone mimics. However, males } \\
\text { are also produced under changing } \\
\text { environmental and stressful conditions. }\end{array}$} \\
\hline & & & No. live offspring / parent & \\
\hline & & & Time to first brood & \\
\hline & & & $\begin{array}{l}\text { Parental growth (length and } \\
\text { body weight; optional) }\end{array}$ & \\
\hline & & & $\begin{array}{l}\text { Presence of ephippia or male } \\
\text { neonates }\end{array}$ & \\
\hline \multirow[t]{6}{*}{ Insecta } & \multirow[t]{2}{*}{$\begin{array}{l}\text { OECD TG 218: Sediment-Water Chironomid } \\
\text { Toxicity Test Using Spiked Sediment }\end{array}$} & \multirow[t]{4}{*}{4} & $\begin{array}{l}\text { Mortality (including } \\
\text { development and emergence) }\end{array}$ & \multirow{4}{*}{$\begin{array}{l}\text { Chironomus are protandrous so care must } \\
\text { be taken when interpreting sex ratio } \\
\text { changes. }\end{array}$} \\
\hline & & & $\begin{array}{l}\text { Time to emergence (males and } \\
\text { females) }\end{array}$ & \\
\hline & \multirow[t]{2}{*}{$\begin{array}{l}\text { OECD TG 219: Sediment-Water Chironomid } \\
\text { Toxicity Test Using Spiked Water }\end{array}$} & & Growth (weight) & \\
\hline & & & Sex ratio & \\
\hline & \multirow{2}{*}{$\begin{array}{l}\text { OECD GD } 239 \text { Guidance Document on Honey } \\
\text { Bee (Apis mellifera) Larval Toxicity Test, } \\
\text { Repeated Exposure }\end{array}$} & \multirow[t]{2}{*}{4} & $\begin{array}{l}\text { Larval mortalities from day } 3 \text { to } \\
\text { day } 8\end{array}$ & \\
\hline & & & $\begin{array}{l}\text { Pupal mortalities from day } 8 \text { to } \\
\text { day } 15 \text { Emergence rate on day } \\
22\end{array}$ & \\
\hline \multirow[t]{8}{*}{ Annelida } & \multirow[t]{2}{*}{ OECD TG 220: Enchytraeid Reproduction Test } & \multirow[t]{2}{*}{4} & Mortality & \\
\hline & & & No. juveniles / adult & \\
\hline & \multirow{3}{*}{$\begin{array}{l}\text { OECD TG 222: Earthworm Reproduction Test } \\
\text { (Eisenia fetida Eisenia andrel) }\end{array}$} & \multirow[t]{3}{*}{4} & Mortality & \\
\hline & & & Growth (weight) & \\
\hline & & & No. juveniles / adult & \\
\hline & \multirow{3}{*}{$\begin{array}{l}\text { OECD TG 225: Sediment-Water Lumbriculus } \\
\text { Toxicity Test Using Spiked Sediment }\end{array}$} & \multirow[t]{3}{*}{4} & Mortality & \\
\hline & & & Biomass & \\
\hline & & & $\begin{array}{l}\text { Reproduction (total No. or } \\
\text { increase in No.) }\end{array}$ & \\
\hline \multirow[t]{2}{*}{ Chelicerata } & \multirow{2}{*}{$\begin{array}{l}\text { OECD TG 226: Predatory mite (Hypoaspis } \\
\text { (Geolaelaps) aculeifer) reproduction test in } \\
\text { soil }\end{array}$} & \multirow[t]{2}{*}{4} & Mortality & \\
\hline & & & $\begin{array}{l}\text { Reproduction (total No. of } \\
\text { juveniles) }\end{array}$ & \\
\hline \multirow[t]{3}{*}{ Insecta } & \multirow{2}{*}{$\begin{array}{l}\text { OECD TG 228: Determination of } \\
\text { Developmental Toxicity to Dipteran Dung } \\
\text { Flies (Scathophaga stercoraria L. }\end{array}$} & \multirow[t]{3}{*}{4} & Mortality & \\
\hline & & & Development & \\
\hline & $\begin{array}{l}\text { (Scathophagidae), Musca autumnalis De Geer } \\
(\text { Muscidae)) }\end{array}$ & & $\begin{array}{l}\text { Emergence (males and } \\
\text { females) }\end{array}$ & \\
\hline \multirow[t]{2}{*}{ Collembola } & \multirow{2}{*}{$\begin{array}{l}\text { OECD TG 232: Collembolan Reproduction } \\
\text { Test in Soil }\end{array}$} & \multirow[t]{2}{*}{4} & Mortality & \\
\hline & & & $\begin{array}{l}\text { Reproduction (total No. of } \\
\text { juveniles) }\end{array}$ & \\
\hline Insecta & $\begin{array}{l}\text { OECD TG 233: Sediment-Water Chironomid } \\
\text { Life-Cycle Toxicity Test }\end{array}$ & 5 & Mortality & \\
\hline & & & Development & \\
\hline & & & Emergence & \\
\hline & & & $\begin{array}{l}\text { Time to emergence (males and } \\
\text { females) }\end{array}$ & \\
\hline & & & Growth (weight) & \\
\hline & & & Reproduction & \\
\hline & & & Fertility & \\
\hline & & & Sex ratio & \\
\hline
\end{tabular}

Page 22/28 


\begin{tabular}{|c|c|c|c|c|}
\hline $\begin{array}{l}\text { Invertebrate } \\
\text { group }\end{array}$ & Test Guideline & $\begin{array}{l}\text { OECD } \\
\text { CF } \\
\text { level }\end{array}$ & Endpoints & Comment \\
\hline \multirow[t]{2}{*}{ Mollusca } & \multirow{2}{*}{$\begin{array}{l}\text { OECD TG 242: Potamopyrgus antipodarum } \\
\text { Reproduction Test }\end{array}$} & \multirow[t]{2}{*}{4} & Mortality & \\
\hline & & & Reproduction (No. of embryos) & \\
\hline \multirow[t]{2}{*}{ Mollusca } & \multirow{2}{*}{$\begin{array}{l}\text { OECD TG 243: Lymnaea stagnalis } \\
\text { Reproduction Test }\end{array}$} & \multirow[t]{2}{*}{4} & Mortality & \\
\hline & & & $\begin{array}{l}\text { Reproduction (No. of egg } \\
\text { clutches) }\end{array}$ & \\
\hline \multirow[t]{5}{*}{ Crustacea } & \multirow[t]{5}{*}{ OPPTS 850.1350: Mysid Chronic Toxicity Test } & \multirow{5}{*}{$\begin{array}{l}\text { Not } \\
\text { listed }\end{array}$} & Mortality & \\
\hline & & & $\begin{array}{l}\text { Time to appearance of } \\
\text { secondary sexual characters }\end{array}$ & \\
\hline & & & Time to first brood & \\
\hline & & & Growth (length and weight) & \\
\hline & & & $\begin{array}{l}\text { Reproduction (No. } \\
\text { young/female) }\end{array}$ & \\
\hline \multirow[t]{8}{*}{ Crustacea } & \multirow{8}{*}{$\begin{array}{l}\text { Mysid Life Cycle Toxicity Test (when OPPTS } \\
850.1350 \text { is finalised as an OCSPP guideline) }\end{array}$} & \multirow[t]{8}{*}{5} & Mortality & OECD declined to validate this assay \\
\hline & & & Time to maturity & \\
\hline & & & Time to $1^{\text {st }} \& 2$ nd brood release & \\
\hline & & & Inter-brood duration & \\
\hline & & & Number of young per female & \\
\hline & & & $\begin{array}{l}\text { Percentage females } \\
\text { reproductively active }\end{array}$ & \\
\hline & & & Total reproduction days & \\
\hline & & & Growth (length and weight) & \\
\hline \multirow[t]{5}{*}{ Crustacea } & \multirow{5}{*}{$\begin{array}{l}\text { OECD GD 201: New Guidance Document on } \\
\text { Harpacticoid Copepod Development and } \\
\text { Reproduction Test with Amphiascus. }\end{array}$} & \multirow[t]{5}{*}{5} & Mortality & \\
\hline & & & $\begin{array}{l}\text { Time to release of first and } \\
\text { second clutch Number of } \\
\text { necrotic/infertile eggs per } \\
\text { clutch Morphological } \\
\text { abnormalities }\end{array}$ & \\
\hline & & & Intersexuality & \\
\hline & & & Population growth rate & \\
\hline & & & Sex ratio & \\
\hline \multirow[t]{6}{*}{ Crustacea } & \multirow[t]{6}{*}{$\begin{array}{l}\text { Daphnia Multigeneration Assay (when TG is } \\
\text { available) }\end{array}$} & \multirow[t]{6}{*}{5} & Mortality & \\
\hline & & & Age at first reproduction & \\
\hline & & & Clutch size & \\
\hline & & & Intrinsic population growth rate & \\
\hline & & & $\begin{array}{l}\text { Number of dead/aborted } \\
\text { embryos/neonates }\end{array}$ & \\
\hline & & & Sex ratio & \\
\hline \multirow[t]{3}{*}{ Nematoda } & \multirow{3}{*}{$\begin{array}{l}\text { ISO 10872:2020: Determination of the toxic } \\
\text { effect of sediment and soil samples on } \\
\text { growth, fertility and reproduction of } \\
\text { Caenorhabditis elegans (Nematoda) }\end{array}$} & \multirow[t]{3}{*}{5} & Survival & \\
\hline & & & Growth & \\
\hline & & & Reproduction & \\
\hline
\end{tabular}

Table 2 Freshwater invertebrate species investigated for ED-related mechanistic, apical, or mechanistic and apical effects in laboratory or field studies published between 2010 and 2020. 


\begin{tabular}{|c|c|c|c|c|c|c|}
\hline Phylum & Species & Number of studies & Lab or Field & Mechanistic & Apical & Mechanistic/Apical \\
\hline \multirow[t]{2}{*}{ Annelida } & Leech spp & 1 & $\mathrm{~F}$ & & 1 & \\
\hline & Lumbriculus variegatus & 1 & $\mathrm{~L}$ & & 1 & \\
\hline Arachnida & Arrenurus spp. & 1 & $\mathrm{~F}$ & & 1 & \\
\hline \multirow[t]{2}{*}{ Cnidaria } & Hydra circumcincta & 1 & $\mathrm{~L}$ & & & 1 \\
\hline & Hydra sp. & 1 & $\mathrm{~L}$ & & 1 & \\
\hline \multirow[t]{21}{*}{ Crustacea } & Amphipods & 1 & $\mathrm{~F}$ & & & 1 \\
\hline & Astacus leptodactylus & 2 & $\mathrm{~L}$ & 2 & & \\
\hline & Ceriodaphnia cornuta & 1 & $L$ & & 1 & \\
\hline & Daphnia magna & 18 & $\mathrm{~L}$ & 1 & 7 & 10 \\
\hline & Diporeia spp. & 1 & $\mathrm{~L}$ & 1 & & \\
\hline & Eudiaptomus gracilis & 1 & $\mathrm{~L}$ & & & 1 \\
\hline & Gammarus fossarum & 4 & $L(3), F(1)$ & 3 & 1 & \\
\hline & Gammarus locusta & 1 & $\mathrm{~L}$ & & 1 & \\
\hline & Gammarus pseudolimnaeus & 1 & $L$ & 1 & & \\
\hline & Gammarus pulex & 1 & $\mathrm{~L}$ & 1 & & \\
\hline & Gammarus spp. & 1 & $\mathrm{~F}$ & & 1 & \\
\hline & Hyalella azteca & 3 & $\mathrm{~L}$ & 2 & 1 & \\
\hline & Macrobrachium borellii & 1 & $\mathrm{~L}$ & 1 & & \\
\hline & Macrobrachium potiuna & 1 & $\mathrm{~L}$ & 1 & & \\
\hline & Macrobrachium rosenbergii & 4 & $\mathrm{~L}$ & 3 & & 1 \\
\hline & Macrobrachium superbum & 1 & $\mathrm{~L}$ & & 1 & \\
\hline & Mesocyclops luckarti & 1 & $\mathrm{~L}$ & & & 1 \\
\hline & Moina macrocopa & 2 & $\mathrm{~L}$ & & 2 & \\
\hline & Monoporeia affinis & 1 & $\mathrm{~L}$ & & 1 & \\
\hline & Procambarus clarkii & 2 & $\mathrm{~L}$ & 1 & & 1 \\
\hline & Procambarus fallax & 1 & $\mathrm{~L}$ & 1 & & \\
\hline \multirow[t]{5}{*}{ Insecta } & Chironomus riparius & 20 & $\mathrm{~L}$ & 12 & 1 & 7 \\
\hline & Chironomus sancticaroli & 1 & $\mathrm{~L}$ & & 1 & \\
\hline & Hexagenia spp. & 1 & $L$ & & 1 & \\
\hline & Hydropsychesp & 2 & $\mathrm{~L} / \mathrm{F}$ & 1 & & 1 \\
\hline & Prodiamesa olivacea & 1 & $L$ & 1 & & \\
\hline \multirow[t]{12}{*}{ Mollusca } & Bithynia tentaculata & 1 & $\mathrm{~L}$ & & 1 & \\
\hline & Corbicula fluminea & 2 & $\mathrm{~L}$ & 1 & 1 & \\
\hline & Lampsilis fasciola & 2 & $\mathrm{~L}$ & & 1 & 1 \\
\hline & Lampsilis siliquoidea & 1 & $\mathrm{~L}$ & & 1 & \\
\hline & Lymnaea stagnalis & 5 & $\mathrm{~L}$ & & 2 & 3 \\
\hline & Mollusc spp. & 1 & $\mathrm{~F}$ & & & 1 \\
\hline & Physa acuta & 4 & $\mathrm{~L}$ & 2 & 2 & \\
\hline & Physa pomilia & 1 & $\mathrm{~L}$ & & 1 & \\
\hline & Planorbarius corneus & 2 & $L, L / F$ & & 1 & 1 \\
\hline & Pomacea lineata & 1 & $\mathrm{~L}$ & & 1 & \\
\hline & Potamopyrgus antipodarum & 8 & $L(4), F(3), L / F$ & & 6 & 2 \\
\hline & Radix balthica & 3 & $L(2), L / F$ & & 3 & \\
\hline
\end{tabular}

Page 24/28 


\begin{tabular}{|c|c|c|c|c|c|c|}
\hline Phylum & Species & Number of studies & Lab or Field & Mechanistic & Apical & Mechanistic/Apical \\
\hline & Unio tumidus & 1 & $\mathrm{~L}$ & 1 & & \\
\hline & Viviparus viviparus & 1 & $\mathrm{~L} / \mathrm{F}$ & & 1 & \\
\hline Platyhelminthes & Flatworm spp. & 1 & $\mathrm{~L}$ & 1 & & \\
\hline Rotifera & Brachionus calyciflorus & 5 & L & 1 & 4 & \\
\hline Macroinvertebrates & Macroinvertebrates & 3 & $F(2), L / F$ & & 2 & 1 \\
\hline
\end{tabular}

Table 3 Saltwater invertebrate species investigated for ED-related mechanistic, apical, or mechanistic and apical effects in laboratory or field studies published between 2010 and 2020.

\begin{tabular}{|c|c|c|c|c|c|c|}
\hline Phylum & Species & Number of studies & Lab or Field & Mechanistic & Apical & Mechanistic/Apical \\
\hline \multirow[t]{3}{*}{ Annelida } & Galeolaria caespitosa & 1 & $\mathrm{~L}$ & & & 1 \\
\hline & Nereis succinea & 1 & $\mathrm{~L}$ & & 1 & \\
\hline & Platynereis dumerilii & 1 & $\mathrm{~L}$ & 1 & & \\
\hline \multirow[t]{13}{*}{ Crustacea } & Acartia tonsa & 1 & $\mathrm{~L}$ & & 1 & \\
\hline & Amphiascus tenuiremis & 1 & $\mathrm{~L}$ & 1 & & \\
\hline & Artemia salina & 1 & $\mathrm{~L}$ & & 1 & \\
\hline & Callinectes sapidus & 1 & L & & & 1 \\
\hline & Carcinus maenas & 2 & $\mathrm{~L} / \mathrm{F}$ & 2 & & \\
\hline & Clibanarius vittatus & 1 & $\mathrm{~L}$ & & 1 & \\
\hline & Diaphanosoma celebensis & 1 & $\mathrm{~L}$ & & & 1 \\
\hline & Echinogammarus marinus & 1 & $\mathrm{~L}$ & & & 1 \\
\hline & Eurytemora affinis & 2 & $\mathrm{~L}$ & 2 & & \\
\hline & Homarus gammarus & 1 & $\mathrm{~F}$ & & 1 & \\
\hline & Paracyclopina nana & 2 & $\mathrm{~L}$ & & & 1 \\
\hline & Tigriopus japonicus & 1 & $\mathrm{~L}$ & & & 1 \\
\hline & Tisbe battagliai & 1 & $\mathrm{~L}$ & & & 1 \\
\hline \multirow[t]{14}{*}{ Mollusca } & Chlamys farreri & 2 & 2 & 1 & & 1 \\
\hline & Crassostrea angulata & 1 & $\mathrm{~L}$ & & & 1 \\
\hline & Crassostrea gigas & 3 & $\mathrm{~L}$ & 2 & & 1 \\
\hline & Crepidula onyx & 1 & $\mathrm{~L}$ & & 1 & \\
\hline & Haliotis diversicolor supertexta & 1 & $\mathrm{~L}$ & & & 1 \\
\hline & Heleobia australis & 1 & $\mathrm{~L}$ & & 1 & \\
\hline & Mytilus edulis & 4 & $L(3), F$ & 2 & & 2 \\
\hline & Mytilus galloprovincialis & 10 & $\mathrm{~L}$ & 9 & 1 & \\
\hline & Mytilus spp. & 1 & $\mathrm{~L}$ & & & 1 \\
\hline & Nucella lapillus & 1 & $\mathrm{~L}$ & 1 & & \\
\hline & Plicopurpura pansa & 1 & $\mathrm{~L}$ & & & 1 \\
\hline & Ruditapes decussatus & 1 & $\mathrm{~L}$ & 1 & & \\
\hline & Ruditapes philippinarum & 2 & $\mathrm{~L}$ & 1 & 1 & \\
\hline & Scrobicularia plana & 1 & $\mathrm{~L}$ & 1 & & \\
\hline \multirow[t]{2}{*}{ Tunicata } & Ciona intestinalis & 4 & $\mathrm{~L}$ & 1 & 2 & 1 \\
\hline & Phallusia mammillata & 1 & $\mathrm{~L}$ & & & \\
\hline Macroinvertebrates & Macroinvertebrate spp. & 1 & $\mathrm{~F}$ & & 1 & \\
\hline
\end{tabular}


Table 4 Terrestrial invertebrate species investigated for ED-related mechanistic, apical, or mechanistic and apical effects in studies published (all laboratory) between 2010 and 2020.

\begin{tabular}{|llllll|}
\hline Phylum & Species & Number of studies & Mechanistic & Apical & Mechanistic/Apical \\
\hline Annelida & Eisenia fetida & 2 & 1 & 1 & \\
\hline & Enchytraeus crypticus & 2 & 1 & 2 & \\
\hline Crustacea & Porcellio scaber & 3 & 1 & 3 & 1 \\
\hline Hexapoda (Collembola) & Folsomia candida & 4 & & 2 \\
\hline Insecta & Bombyx mori & 1 & & 1 & 1 \\
\hline & Drosophila melanogaster & 4 & & 1 & 1 \\
\hline & Euborellia annulipes & 1 & & 1 & 1 \\
\hline & Lasius niger & 1 & & 1 & 1 \\
\hline & Spodoptera exigua & 1 & & & 1 \\
\hline
\end{tabular}

Table 5 Substances tested five or more times in studies on invertebrate ED published between 2010 and 2020.

\begin{tabular}{|lll|}
\hline Substance & Substance type & Number of studies \\
\hline Bisphenol A [BPA] & Industrial chemical & 32 \\
\hline Tributyltin [TBT] & Biocide & 15 \\
\hline 17 alpha-ethinylestradiol [EE2] & Pharmaceutical & 13 \\
\hline 17 beta-estradiol [E2] & Pharmaceutical & 13 \\
\hline Vinclozolin & Insecticide/herbicide/fungicide & 9 \\
\hline Nonylphenol & Industrial chemical & 8 \\
\hline Fluoxetine & Pharmaceutical & 8 \\
\hline Benzophenone-3 [BP3] & UV filter & 8 \\
\hline Di(2-ethylhexyl) phthalate [DEHP] & Industrial chemical & 7 \\
\hline Chlordecone & Insecticide/herbicide/fungicide & 6 \\
\hline Cadmium & Metal/metalloid & 6 \\
\hline WWTP effluent & Mixture & 6 \\
\hline 4-methylbenzylidene camphor [4MBC] & UV filter & 6 \\
\hline Triclosan & Biocide & 5 \\
\hline
\end{tabular}

Table 6 Example definition of Specific Protection Goals for invertebrates potentially exposed to an insecticide (Hommen et al. 2015) 


\begin{tabular}{|c|c|c|c|c|c|c|c|c|}
\hline $\begin{array}{l}\text { Ecosystem } \\
\text { services } \\
\text { key driver }\end{array}$ & Problem & Focal species & Entity & Attribute & $\begin{array}{l}\text { Spatial } \\
\text { scale }\end{array}$ & $\begin{array}{l}\text { Temporal } \\
\text { scale }\end{array}$ & $\begin{array}{l}\text { Model } \\
\text { type }\end{array}$ & $\begin{array}{l}\text { Model } \\
\text { output }\end{array}$ \\
\hline $\begin{array}{l}\text { Soil } \\
\text { invertebrates }\end{array}$ & $\begin{array}{l}\text { Effects of application } \\
\text { scenarios on populations }\end{array}$ & $\begin{array}{l}\text { Eisenia fetida, } \\
\text { Folsomia } \\
\text { candida }\end{array}$ & Population & $\begin{array}{l}\text { Abundance } \\
\text { \& biomass }\end{array}$ & In-crop & 1 year & $\begin{array}{l}\text { Spatially } \\
\text { explicit IBM }\end{array}$ & $\begin{array}{l}\text { Time to } \\
\text { recovery }\end{array}$ \\
\hline $\begin{array}{l}\text { Terrestrial } \\
\text { invertebrates }\end{array}$ & Recovery of populations & $\begin{array}{l}\text { Linyphyiid spiders, } \\
\text { carabid beetle }\end{array}$ & Population & Abundance & $\begin{array}{l}\text { In- } \\
\text { field/off- } \\
\text { field }\end{array}$ & $\begin{array}{l}\text { A few } \\
\text { years }\end{array}$ & $\begin{array}{l}\text { Spatially } \\
\text { explicit } \\
\text { IBM }\end{array}$ & $\begin{array}{l}\text { Time to } \\
\text { recovery }\end{array}$ \\
\hline $\begin{array}{l}\text { Aquatic } \\
\text { invertebrates }\end{array}$ & $\begin{array}{l}\text { Effects of time } \\
\text { variable } \\
\text { exposure on } \\
\text { populations }\end{array}$ & $\begin{array}{l}\text { Gammarus, } \\
\text { Chaoborus, } \\
\text { Daphnia }\end{array}$ & Population & Abundance & $\begin{array}{l}\text { Edge of } \\
\text { field } \\
\text { water } \\
\text { body }\end{array}$ & $\begin{array}{l}1 \text { to a } \\
\text { few } \\
\text { years }\end{array}$ & $\begin{array}{l}\text { Toxicokinetic- } \\
\text { Toxicodynamic } \\
\& \\
\text { Individual- } \\
\text { Based Model } \\
\text { (IBM) }\end{array}$ & $\begin{array}{l}\text { Magnitude } \\
\text { and } \\
\text { duration } \\
\text { of effect }\end{array}$ \\
\hline
\end{tabular}

Table 7 Adverse outcome pathway of ecdysone receptor agonism leading to incomplete ecdysis-associated mortality. MIE: Molecular initiating event; KE: Key event; AO: Adverse Outcome; EcR: ecdysone receptor, E75b: nuclear receptor E75B; Ftz-f1: Fushi tarazu factor-1; Eth: ecdysis triggering hormone; Ccap: crustacean cardioactive peptide D = Direct; I = Indirect; S = Strong; $M=$ Moderate; $W$ = Weak (Song et al. 2017) 


\begin{tabular}{|c|c|c|c|c|c|c|c|c|c|}
\hline KE & $\begin{array}{l}\text { Event } \\
\text { description }\end{array}$ & $\begin{array}{l}\text { Level of } \\
\text { organisation }\end{array}$ & $\begin{array}{l}\text { Upstream to } \\
\text { downstream } \\
\text { KE } \\
\text { relationship }\end{array}$ & $\begin{array}{l}\text { Support for } \\
\text { essentiality }\end{array}$ & $\begin{array}{l}\text { Biological } \\
\text { plausibility }\end{array}$ & $\begin{array}{l}\text { Empirical } \\
\text { support }\end{array}$ & $\begin{array}{l}\text { Overall } \\
\text { WoE }\end{array}$ & $\begin{array}{l}\text { Quantitative } \\
\text { understanding }\end{array}$ & Detection method \\
\hline MIE & $\begin{array}{l}\text { EcR, } \\
\text { activation }\end{array}$ & Macromolecular & $D$ & $S$ & S & S & $S$ & W & $\begin{array}{l}\text { In vitro ECR binding } \\
\text { assay; transcriptional } \\
\text { analysis }\end{array}$ \\
\hline $\begin{array}{l}\text { KE- } \\
1\end{array}$ & $\begin{array}{l}\text { E75b gene, } \\
\text { induction }\end{array}$ & Molecular/cellular & $D$ & S & S & S & $S$ & W & $\begin{array}{l}\text { Transcriptional } \\
\text { analysis }\end{array}$ \\
\hline $\begin{array}{l}\text { KE- } \\
2\end{array}$ & $\begin{array}{l}\text { Ftz-f1 gene, } \\
\text { suppression }\end{array}$ & Molecular/cellular & $\mathrm{D}$ & M & S & $M$ & M & W & $\begin{array}{l}\text { Transcriptional } \\
\text { analysis }\end{array}$ \\
\hline $\begin{array}{l}\text { KE- } \\
3\end{array}$ & $\begin{array}{l}\text { Release of } \\
\text { circulating } \\
\text { Eth, } \\
\text { reduction }\end{array}$ & Tissue/organ & I & S & S & M & M & W & $\begin{array}{l}\text { Enzyme } \\
\text { immunoassay; } \\
\text { immunohistochemical } \\
\text { staining }\end{array}$ \\
\hline $\begin{array}{l}\text { KE- } \\
4\end{array}$ & $\begin{array}{l}\text { Release of } \\
\text { circulating } \\
\text { Ccap, } \\
\text { reduction }\end{array}$ & Tissue/organ & $D$ & S & S & M & M & W & $\begin{array}{l}\text { Enzyme } \\
\text { immunoassay; } \\
\text { immunohistochemical } \\
\text { staining }\end{array}$ \\
\hline $\begin{array}{l}\text { KE- } \\
5\end{array}$ & $\begin{array}{l}\text { Ecdysis } \\
\text { motoneuron } \\
\text { burts, } \\
\text { reduction }\end{array}$ & Tissue/organ & $D$ & $S$ & $S$ & M & $M$ & W & $\begin{array}{l}\text { Electrophysiological } \\
\text { recording }\end{array}$ \\
\hline $\begin{array}{l}\text { KE- } \\
6\end{array}$ & $\begin{array}{l}\text { Excitatory } \\
\text { postsynaptic } \\
\text { potential, } \\
\text { reduction }\end{array}$ & Tissue/organ & $D$ & M & S & M & M & W & $\begin{array}{l}\text { Electrophysiological } \\
\text { recording; FM1-43 } \\
\text { fluorescent labelling }\end{array}$ \\
\hline $\begin{array}{l}\text { KE- } \\
7\end{array}$ & $\begin{array}{l}\text { Abdominal } \\
\text { muscle } \\
\text { contraction, } \\
\text { reduction }\end{array}$ & Tissue/organ & $D$ & M & S & M & M & W & $\begin{array}{l}\text { Electrophysiological } \\
\text { recording; behavioural } \\
\text { (air/water } \\
\text { swallowing) assays }\end{array}$ \\
\hline $\begin{array}{l}\text { KE- } \\
8\end{array}$ & $\begin{array}{l}\text { Incomplete } \\
\text { ecdysis, } \\
\text { induction }\end{array}$ & Individual & $D$ & S & $S$ & S & $S$ & S & $\begin{array}{l}\text { Light microscope, } \\
\text { histopathology }\end{array}$ \\
\hline $\mathrm{AO}$ & $\begin{array}{l}\text { Mortality, } \\
\text { increased }\end{array}$ & Individual & $D$ & S & S & S & S & St & Survival test \\
\hline
\end{tabular}

